\title{
Definition of the viral targets of protective HIV-1-specific T cell responses
}

\author{
Beatriz Mothe ${ }^{1,2,3}$, Anuska Llano ${ }^{1}$, Javier Ibarrondo ${ }^{1}$, Marcus Daniels ${ }^{4}$, Cristina Miranda ${ }^{2}$, Jennifer Zamarreño ${ }^{1}$, \\ Vanessa Bach', Rosario Zuniga ${ }^{5}$, Susana Pérez-Álvarez ${ }^{1,6}$, Christoph T Berger $^{7}$, Maria C Puertas ${ }^{1}$, \\ Javier Martinez-Picado ${ }^{1,8}$, Morgane Rolland ${ }^{9}$, Marilu Farfann, James J Szinger ${ }^{4}$, William H Hildebrand ${ }^{10}$, \\ Otto O Yang ${ }^{11}$, Victor Sanchez-Merino ${ }^{12}$, Chanson J Brumme ${ }^{13}$, Zabrina L Brumme ${ }^{13,14}$, David Heckerman ${ }^{15}$, \\ Todd M Allen7, James I Mullins ${ }^{16}$, Guadalupe Gómez ${ }^{16}$, Philip J Goulder ${ }^{17,18}$, Bruce D Walker ${ }^{7,18,19}$, Jose M Gatell ${ }^{12}$, \\ Bonaventura Clotet $^{1,2}$, Bette T Korber ${ }^{4,20}$, Jorge Sanchez ${ }^{5}$ and Christian Brander ${ }^{1,8^{*}}$
}

\begin{abstract}
Background: The efficacy of the CTL component of a future HIV-1 vaccine will depend on the induction of responses with the most potent antiviral activity and broad HLA class I restriction. However, current HIV vaccine designs are largely based on viral sequence alignments only, not incorporating experimental data on T cell function and specificity.

Methods: Here, 950 untreated HIV-1 clade B or -C infected individuals were tested for responses to sets of 410 overlapping peptides (OLP) spanning the entire HIV-1 proteome. For each OLP, a "protective ratio" (PR) was calculated as the ratio of median viral loads $(\mathrm{VL})$ between OLP non-responders and responders.
\end{abstract}

Results: For both clades, there was a negative relationship between the PR and the entropy of the OLP sequence. There was also a significant additive effect of multiple responses to beneficial OLP. Responses to beneficial OLP were of significantly higher functional avidity than responses to non-beneficial OLP. They also had superior in-vitro antiviral activities and, importantly, were at least as predictive of individuals' viral loads than their HLA class I genotypes.

Conclusions: The data thus identify immunogen sequence candidates for HIV and provide an approach for T cell immunogen design applicable to other viral infections.

Keywords: HIV specific CTL, clade B, clade C, HLA, vaccine immunogen design, functional avidity, epitope, entropy, immune correlate

\section{Background}

HIV-1 infection induces strong and broadly directed HLA class I restricted T cell responses for which specific epitopes and restricting HLA class I alleles have been associated with relative in vivo viral control [1]. The bulk of the anti-viral CTL response appears to be disproportionately HLA-B restricted, but the relative contribution of targeted viral regions and restricting HLA molecules on the effectiveness of these responses remains unclear [2-5]. In addition, the impact of HIV-1

\footnotetext{
* Correspondence: cbrander@irsicaixa.es

'Irsicaixa AIDS Research Institute-HIVACAT, Badalona, Spain

Full list of author information is available at the end of the article
}

sequence diversity on the effectiveness of virus-specific $\mathrm{T}$ cell immunity in vivo is unclear, as functional constraints of escape variants, codon-usage at individual protein positions, $\mathrm{T}$ cell receptor (TCR) plasticity and functional avidity and cross-reactivity potential may all contribute to the overall antiviral activity of a specific $\mathrm{T}$ cell response [6-13]. Of note, $\mathrm{T}$ cell responses to Gag have most consistently been associated with reduced viral loads in both clade $B$ and clade $C$ infected cohorts [14-16]; however, the specific regions in Gag responsible for this effective control remain poorly defined. In addition, it is unclear whether the relative benefit of Gag is due to any other specific characteristic of this protein, such as rapid antigen-representation upon infection,

\section{Biomed Central}

(c) 2011 Mothe et al; licensee BioMed Central Ltd. This is an Open Access article distributed under the terms of the Creative Commons Attribution License (http://creativecommons.org/licenses/by/2.0), which permits unrestricted use, distribution, and reproduction in any medium, provided the original work is properly cited. 
protein expression levels, amino acid composition and/ or inherently greater processability and immunogenicity, particularly in the context of selected HLA class I alleles $[17,18]$. Thus, concerns remain that a purely Gag-based vaccine might mainly benefit those people with a particular HLA genotype and will not take advantage of potentially beneficial targets outside of Gag $[4,16,17,19]$. In addition, CTL escape and viral fitness studies have focused largely on Gag-derived epitopes presented in the context of protective HLA class I alleles such as HLA-B27 and -B57 [7,20,21], yielding results that may not be generalizable to the genetically diverse majority of the human population. Furthermore, many studies have focused on immunodominant targets only, despite some studies in HIV-1 and SIV infection demonstrating a crucial contribution of sub-dominant responses to targets outside of Gag to the effective in-vivo viral control $[4,22]$. Thus, the current view on what may constitute a protective cellular immune response to HIV-1 is likely biased towards a immunodominant responses and those restricted by frequent HLA class I alleles and HLA alleles associated with superior disease outcome.

To overcome these potential limitations, the design of an effective and broadly applicable HIV-1 vaccine should to be based on information gained through comprehensive analyses that extend across large portions of the population's HLA class I heterogeneity. Here we focus on three cohorts totaling more than 950 untreated, chronically HIV-1 infected individuals with clade $B$ and $C$ infections, from which responses to certain regions of the viral genome and specific $\mathrm{T}$ cell response patterns emerge as correlates of viral control. Importantly, the analyses identify functional properties unique to these responses and control for the impact of HLA class I alleles known to be associated with superior control of HIV-1 infection, thus providing vaccine immunogen sequence candidates with potential usefulness in a broadly applicable HIV-1 vaccine.

\section{Methods}

\section{Cohorts}

A HIV clade B infected cohort of 223 chronically infected, treatment naïve individuals was recruited and tested at IMPACTA in Lima, Peru. The majority (78\%) of enrollees were male and all recruited individuals considered themselves to be of a mixed Amerindian ethnicity [14]. The cohort had a median viral load 37,237 copies/ml (range $<50->750,000$ ) and a median CD4 count of 385 cell/ul (range170-1151). A second clade B infected cohort was established at the HIV-1 outpatient clinic "Lluita contra la SIDA" at Hospital Germans Trias i Pujol in Badalona (Barcelona, Spain) consisting of 48 treatment-naïve subjects with viral loads below 10,000 and CD4 cell counts > 350 cells $/ \mathrm{mm}^{3}$ ("controllers", $\mathrm{n}=$
24) or above 50,000 copies/ml and CD4 cell counts < 350 cells $/ \mathrm{mm}^{3}$ ("non-controllers", $\mathrm{n}=24$ ). The HIV-1 clade $\mathrm{C}$ infected cohort has been described in the past and consisted of 631 treatment naïve South African with a median viral load of 37,900 copies/ml (range < 50-> 750,000 ) and a median CD4 count of 393 cells/ul (range 1-1378) [16]. An additional 78 from a recently published cohort in Boston were included in the analyses of functional avidities [23-29]. HLA typing was performed as previously described using SSP-PCR [30]. For Hepitope and FASS analyses, 4digit typing was used for the Lima cohort and 2-digit typing for the Durban cohort. Protocols were approved in Lima by the IMPACTA Human Research Committee, in Durban by the Ethical Committee of the Nelson R. Mandela School of Medicine at the University of KwaZulu-Natal and in Barcelona by the Human Research Committee at Hospital Germans Trias i Pujol. All subjects provided written informed consent.

Peptide test set and ELISpot assay: Previously described peptide sets matching HLA-clade B and C consensus sequences were used in all experiments for which the OLP-specific entropies have been calculated in the past, based on available sequence datasets [31-33] and http://www.hiv.lanl.gov/content/immunology/hlatem/index.html. The peptides were clade-specific sets of adapted 18 mers, overlapping by 11 residues designed using the PeptGen tool available at the Los Alamos HIV database http://www.hiv.lanl.gov/content/sequence/ PEPTGEN/peptgen.html. The individual OLP in the peptide sets for clade $B$ and clade $C$ had all the same starting and ending position relative to the source protein and follow the same numbering across the entire viral proteome for both clades. Peripheral blood mononuclear cells (PBMCs) were separated from whole blood by density centrifugation and used directly to test for $\mathrm{CD}^{+} \mathrm{T}$ cell responses in vitro. IFN- $\gamma$ ELISpot assays were performed as described previously, using Mabtech antibodies (Mabtech, Stockholm, Sweden) and a matrix format that allowed simultaneous testing of all 410 overlapping (OLP) peptides in the respective test set [14]. Thresholds for positive responses were defined as: exceeding 5 spots $\left(50 \mathrm{SFC} / 10^{6}\right.$ ) per well and exceeding the mean of negative wells plus 3 standard deviation or three times the mean of negative wells, whichever was higher. Stimulation with PHA was used as a positive control in all ELISpot assays.

\section{Definition of functional avidity}

Responses targeting 18 mer OLP in HIV-1 Gag p24 were assessed for their functional avidity using OLP-specific sets of 10 mer peptides overlapping by 9 residues that span the 18 mer peptide sequence. Functional avidity was defined as the peptide concentration needed to elicit half maximal response rates in the ELISpot assay 
and was calculated as a sigmoidal dose response curve fit using GraphPad Prism software [13].

\section{In vitro viral replication inhibition assay}

A double mutant virus containing a Nef M20A and Integrase G140S/Q148H Raltegravir (integrase inhibitor) resistance mutations was tested for replication in CD4 T cells in the presence or absence of autologous $\mathrm{T}$ cell lines targeting protective or non-protective OLP. Use of the Raltegravir-resistant virus allows to prevent potential replication of autologous virus in the inhibition assays [28], excludes potential negative impacts on antigen processing or CTL functions attributed to protease inhibitors [34] and avoids overlap between the resistance mutations sites (i.e. G140S/Q148H) and location of beneficial and non-beneficial OLP sequences. In brief, the p83-10 plasmid containing mutations for a methionine to alanine substitution at position 20 of the Nef protein and the p83-2 plasmid engineered to contain the G140S and Q148H mutations in the integrase were combined to produce a virus that is replication competent, highly resistant to Raltegravir and does not downregulate HLA class I in infected cells $[35,36]$. Although not entirely physiological, this approach was chosen to potentially increase the signal in the in vitro inhibition assay, even when responses were restricted by Nef-sensitive HLA class I alleles. Plasmids were co-transfected into MT4 cells and virus was harvested after 7 days $[35,37,38]$. Autologous CD4 cells were enriched by magnetic beads isolation (Miltenyi) and expanded for 3 days using a bispecific anti-CD3/8 antibody and IL-2 containing medium (50 IU r-IL2) before infecting them at multiplicities of infection (MOI) between 0.01 and 1. Effector cells were obtained by stimulating PBMC with either beneficial or non-beneficial OLP for 12 days before isolating specific OLP-reactive cells by IFN- $\gamma$ capture assay according to manufacturers' instructions (Miltenyi, Bergisch Gladbach, Germany). The effector T cells were analyzed by flow cytometry for the specificity to their respective targets after capture assay and quantified to adjust effector-to-target ratios. Since the NL4-3 backbone sequence differed in several positions in beneficial and non-beneficial OLP, the epitope specificity was predicted based on the HLA class I genotype of the tested individual and responses confirmed to efficiently recognize variant sequences in the NL4-3 backbone sequence. Culture supernatant was harvested and replaced by Raltegravir containing medium $0.05 \mu \mathrm{g} / \mathrm{ml}$ after $72 \mathrm{~h}$. Levels of Gagp24 in the culture supernatant were determined by ELISA as described [39].

\section{Statistical Analyses}

Statistical analyses were performed using Prism Version 5 and R Statistical Language [40]. Results are presented as median values unless otherwise stated. Tests included ANOVA, non-parametric Mann-Whitney test (twotailed) and Spearman rank test. The significance of differences in viral load distribution between OLP-responders and OLP-non-responders was assessed by a twosided Student's T Test with multiple tests addressed using, instead of a Bonferroni correction, a q-value approach to compensate for multiple comparisons [39]. The multivariate analysis was based on a novel multivariate combined regression method known as FASS, a forward selection method combined with all-subsets regression [41-43]. Briefly, the FASS approach works by iteratively performing the following procedure: Let ' $\mathrm{V}$ ' be the set of all variables and ' $M$ ' be the set of variables included in a model. In the first step, those variables that are not already in the model are divided into equalsized blocks of variables (the last block may have less than 'g' variables). Then, for each block of variables, ' $m$ ' is a new estimated and evaluated model using the Bayesian Information Criterion (BIC). The best model ' $m$ ' according to its $\mathrm{BIC}$ is retained and the procedure starts all over again until in one step or more the model is not improved.

\section{Results}

HIV-1-specific T cell responses targeting conserved regions are associated with lower viral loads

In a first analysis, HIV-1-specific $\mathrm{T}$ cell responses were assessed in a cohort of 223 HIV-1 clade B infected individuals recruited in Lima, Peru using IFNg ELISpot assays and a previously described set of 410 clade B overlapping peptides (OLP) [14,31]. For each OLP, a protective ratio (PR) was calculated as the ratio of the median viral loads between OLP non-responders and OLP responders, such that OLP with $P R>1$ were reflective of OLP predominantly targeted by individuals with reduced viral loads. OLP-specific PR were a) compared between OLP spanning the different viral proteins and b) correlated with the viral sequence heterogeneity in the region covered by the OLP. The data showed highest median PR values for OLP spanning the Gag protein sequence, whereas Nef, Env and Tat had the lowest median PR values (Figure 1A, p $<0.0001$, ANOVA). A protein-subunit-breakdown of PR values showed the p15 subunit of Gag and RT in Pol to score less favorable than the remainder of the respective proteins (Figure $1 \mathrm{~B}, \mathrm{p}=0.0032$ and $\mathrm{p}=0.0025$, respectively). While these data confirm the association between HIV-1 Gag-specific responses and lower viral loads, it is important to note that all proteins contained OLP with $\mathrm{PR}>1$, suggesting that some beneficial responses can be located outside of Gag; data that has not emerged from any of the previous studies linking Gag responses to relative viral control. At the same 


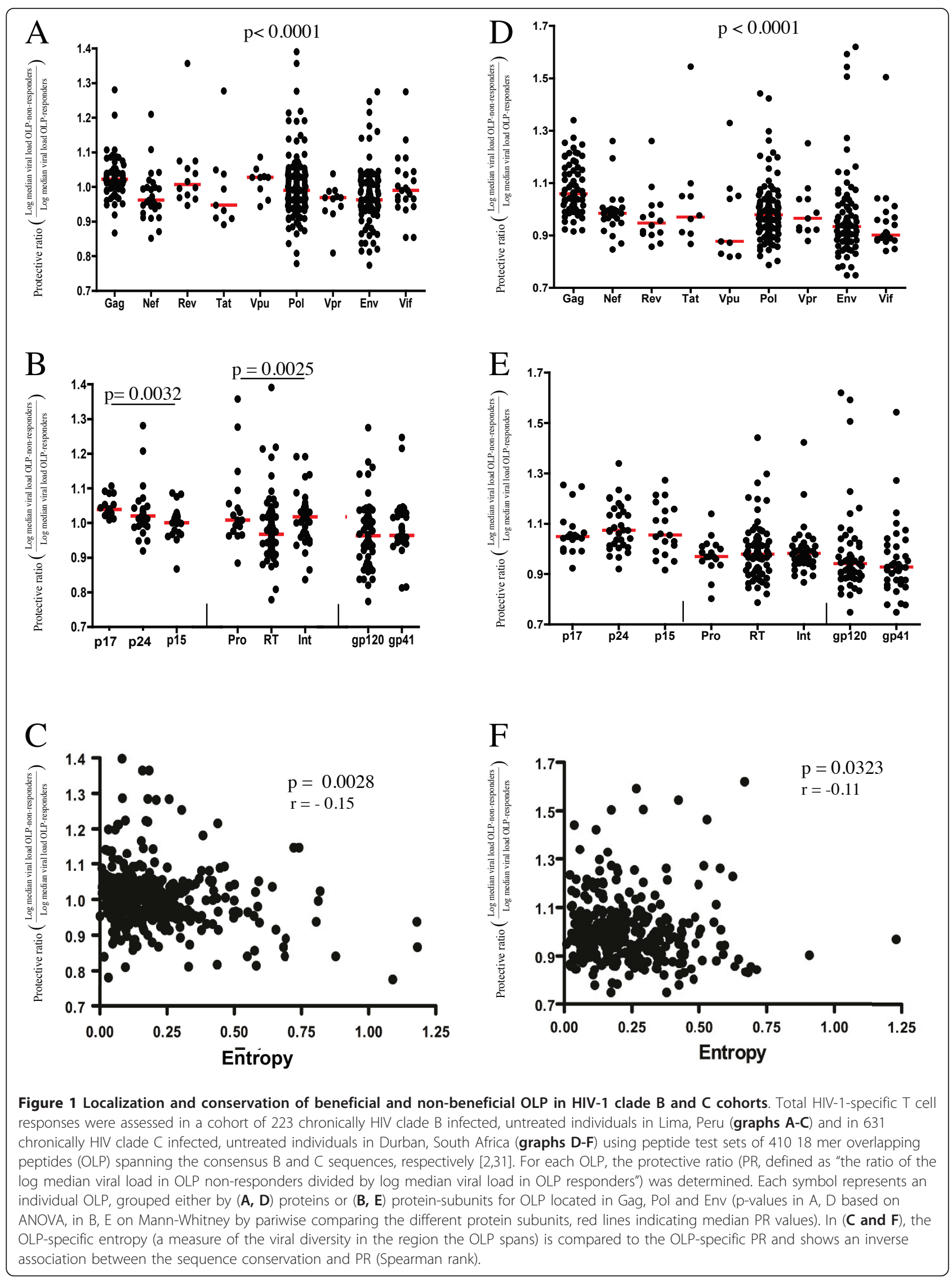


time, all proteins contained OLP with $\mathrm{PR}<1$, indicating that proteins considered overall beneficial may contain non-beneficial regions as well. In addition, when the OLP-specific PR was compared to the sequence entropy of the region spanned by the individual OLP, a significant negative correlation between $\mathrm{PR}$ and entropy was observed $(\mathrm{p}=0.0028, \mathrm{r}=-0.15$; Figure $1 \mathrm{C})$. Although rarely targeted OLP may have introduced statistically less robust data points in this comparison and caused a wide scatter of data points, the results show a relative absence of OLP with high entropy and high PR values, suggesting that responses to more variable regions are less effective in mediating in vivo viral control.

To assess whether the above observations would also hold true outside of clade B infection, the same analyses were conducted in a cohort of 631 clade C HIV-1 infected subjects enrolled in Durban, South Africa and tested for responses against a clade $C$ consensus OLP sequence as described previously [33]. As in clade B infection, the OLP specific PR values were highest for OLP spanning Gag without any significant differences between the Gag and Pol protein subunits (Figure 1D and $1 \mathrm{E})$. As in the clade $B$ cohort, the PR values were negatively correlated with the OLP-specific entropy ( $\mathrm{p}=$ 0.0323 , Figure $1 F)$, confirming the findings in the clade $\mathrm{B}$ cohort and further pointing towards the importance of targeting conserved segments of the viral proteome for effective in vivo viral control.

\section{Identification of individual beneficial OLP sequences in clade $B$ and $C$ infection}

In order to identify individual OLP that were significantly more frequently targeted in individuals with relative viral control and to compare the beneficial OLP in clade $B$ and $C$ infection, the viral load distribution in OLP-responders and non-responders was analyzed individually for each OLP. For the clade B cohort in Peru, the analyses yielded 43 OLP sequences for which the median viral load differed between the two groups with an uncorrected $p$-value of $<0.05$. Of these 43 OLP, 26 were OLP with a PR > 1 (referred to as "beneficial" OLP), and 17 OLP with a PR $<1$ ("non-beneficial" OLP, Table 1). The distribution of OLP with PR $>1$ among viral proteins was biased towards Gag and Pol, while Env produced exclusively OLP with $\mathrm{PR}<1$ (Figure 2A).

The same analyses were repeated for the clade $\mathrm{C}$ cohort in Durban, which due to its larger size allowed to apply more stringent statistical criteria to identify beneficial and non-beneficial OLP. To compensate for multiple statistical comparisons, we employed a previously described false-discovery rate approach [39], resulting in the identification of 33 clade C OLP with q-values of $<0.2$ (i.e. OLP with significantly different viral load distributions between OLP-responders and non-responders with a false positive discovery rate (q-value) of 20\%). The 33 OLP identified were comprised of 22 beneficial OLP and 11 non-beneficial OLP, with the beneficial OLP being again located in Gag, Pol and Vif, similar to what was seen in the clade B cohort (Figure 2B).

In both cohorts, the total breadth and magnitude of responses did not correlate with viral loads as reported for parts of these cohorts in the past $[14,16]$. The OLP with significant differences in median viral loads (43 OLP in clade B and 33 OLP in clade C, Tables 1 and 2, respectively, i.e. "scoring OLP"), were more often targeted in their respective cohort than OLP that did not score with a significant difference in viral loads ( $\mathrm{p}=$ 0.0015 Lima; $p<0.0001$ Durban). However, beneficial and non-beneficial OLP were equally frequently targeted in either cohort. Also, there was no difference in the median magnitude of the OLP-specific responses, regardless whether it was a beneficial, non-beneficial or not-scoring OLP (all p > 0.7, data not shown). Finally, there was no correlation between the number of total OLP responses (against all 410 OLP) and the magnitude of responses to beneficial OLP in either cohort, indicating that the strength of beneficial OLP responses was not diminished by other responses to the rest of the viral proteome.

In the clade $B$ cohort, the 26 beneficial and 17 nonbeneficial OLP showed a significant difference in their median entropy ( $p=0.0327$, Figure $2 C$ ), in line with the overall negative association between higher PR and lower sequence entropy seen in the comprehensive screening including the entire 410 OLP set (Figure 1C). While this comparison was not significant in clade $C$ infection, a detailed look at Gag showed that beneficial Gag clade C OLP had a lower entropy values than the rest of the Gag OLP, suggesting that targeting of the most conserved regions even in Gag provided particular benefits for viral control (Figure $2 \mathrm{D}, \mathrm{p}=0.0172$ ). These beneficial OLP were also more frequently targeted (median of 36 responders) compared to the rest of Gag OLP (median 12 responders, $\mathrm{p}=0.0099$ ), likely reflecting the high epitope density in these regions $[33,44]$.

Finally, the two cohorts showed a partial overlap in the targeted beneficial and non-beneficial OLP, despite the vastly different HLA genetics in these two populations $[4,31,45,46]$. As Gag was enriched in beneficial OLP scattered throughout the entire protein sequence, we used the available reverse transcriptase (RT) protein structure to assess whether beneficial responses were targeting structurally related regions of the protein, even though the linear position of beneficial OLP did not precisely match between the two clades. Indeed, superimposing the locations of beneficial OLP in the RT protein indicates that in both clades, beneficial OLP fell in structurally related domains of the RT protein (Figure 
Table 1 Beneficial and non-beneficial OLP identified in Lima clade B cohort $(p<0.05)$

\begin{tabular}{|c|c|c|c|c|c|c|c|}
\hline OLP \# & Protein & Sub-unit & $\begin{array}{l}\text { OLP clade B } \\
\text { consensus } \\
\text { sequence }\end{array}$ & $\begin{array}{l}\text { Median viral } \\
\text { load in OLP } \\
\text { responders }\end{array}$ & $\begin{array}{c}\text { Median viral } \\
\text { load in OLP } \\
\text { non-responders }\end{array}$ & $\begin{array}{l}\text { Protective Ratio } \\
\text { (PR)* }\end{array}$ & $\mathrm{p}$-value \\
\hline 3 & Gag & p17 & EKIRLRPGGKKKYKLKHI & 22947 & 39014 & 1.053 & 0.037 \\
\hline 6 & Gag & p17 & ASRELERFAVNPGLL & 15380 & 43189 & 1.107 & 0.001 \\
\hline 7 & Gag & p17 & ERFAVNPGLLETSEGCR & 25939 & 38974 & 1.040 & 0.049 \\
\hline 10 & Gag & p17 & QLQPSLQTGSEELRSLY & 16285 & 37237 & 1.085 & 0.031 \\
\hline 12 & Gag & p17 & SLYNTVATLYCVHQRIEV & 23855 & 37113 & 1.044 & 0.037 \\
\hline 23 & Gag & p24 & AFSPEVIPMFSALSEGA & 22947 & 37113 & 1.048 & 0.036 \\
\hline 31 & Gag & p24 & IAPGQMREPRGSDIA & 3563 & 35483 & 1.281 & 0.028 \\
\hline 34 & Gag & p24 & STLQEQIGWMTNNPPIPV & 6127 & 37360 & 1.207 & 0.002 \\
\hline 48 & Gag & p24 & ACQGVGGPGHKARVLAEA & 12975 & 35755 & 1.107 & 0.041 \\
\hline 60 & Gag & p15 & GKIWPSHKGRPGNFLQSR & 16266 & 36434 & 1.083 & 0.044 \\
\hline 75 & Nef & - & WLEAQEEEEVGFPVRPQV & 13407 & 37360 & 1.108 & 0.026 \\
\hline 76 & Nef & - & EVGFPVRPQVPLRPMTYK & 59618 & 29855 & 0.937 & 0.001 \\
\hline 84 & Nef & - & NYTPGPGIRYPLTFGWCF & 55402 & 30538 & 0.945 & 0.006 \\
\hline 85 & Nef & - & RYPLTFGWCFKLVPV & 69890 & 29903 & 0.924 & 0.002 \\
\hline 90 & Nef & - & SLHGMDDPEKEVLWWKF & 89687 & 32650 & 0.911 & 0.042 \\
\hline 159 & Pol & Pro & KMIGGIGGFIKVRQYDQI & 14736 & 36434 & 1.094 & 0.020 \\
\hline 160 & Pol & Pro & FIKVRQYDQILIEICGHK & 3682 & 35755 & 1.277 & 0.031 \\
\hline 161 & $\mathrm{Pol}$ & Pro & QILIEICGHKAIGTVLV & 9117 & 35483 & 1.149 & 0.050 \\
\hline 163 & Pol & Pro & LVGPTPVNIIGRNLLTQI & 25965 & 45637 & 1.055 & 0.007 \\
\hline 171 & $\mathrm{Pol}$ & RT & LVEICTEMEKEGKISKI & 1865 & 35483 & 1.391 & 0.014 \\
\hline 181 & Pol & RT & LDVGDAYFSVPLDKDFRK & 65858 & 32871 & 0.937 & 0.041 \\
\hline 195 & Pol & RT & LRWGFTTPDKKHQKEPPF & 5624 & 37113 & 1.219 & 0.006 \\
\hline 196 & Pol & RT & DKKHQKEPPFLWMGYELH & 10103 & 35483 & 1.136 & 0.044 \\
\hline 210 & Pol & RT & EIQKQGQGQWTYQIY & 18155 & 35483 & 1.068 & 0.045 \\
\hline 222 & Pol & RT & PPLVKLWYQLEKEPIVGA & 412599 & 34640 & 0.808 & 0.030 \\
\hline 230 & Pol & RT & IHLALQDSGLEVNIV & 85102 & 34117 & 0.919 & 0.030 \\
\hline 237 & Pol & RT & VYLAWVPAHKGIGGNEQV & 85102 & 34117 & 0.919 & 0.029 \\
\hline 240 & Pol & RT & SAGIRKVLFLDGIDKA & 116902 & 32761 & 0.891 & 0.019 \\
\hline 269 & Pol & Int & TKELQKQITKIQNFRVYY & 6629 & 35755 & 1.192 & 0.030 \\
\hline 270 & Pol & Int & TKIQNFRVYYRDSRDPLW & 18171 & 37360 & 1.073 & 0.019 \\
\hline 271 & Pol & Int & YYRDSRDPLWKGPAKLLW & 25939 & 35755 & 1.032 & 0.043 \\
\hline 276 & Pol & Int & KIIRDYGKQMAGDDCVA & 6629 & 35755 & 1.192 & 0.021 \\
\hline 279 & Vpr & - & GPQREPYNEWTLELLEEL & 60222 & 32650 & 0.944 & 0.042 \\
\hline 307 & Env & Gp120 & DLNNNTNTTSSSGEKMEK & 179419 & 34117 & 0.863 & 0.044 \\
\hline 311 & Env & Gp120 & IRDKVQKEYALFYKLDW & 179419 & 32871 & 0.860 & 0.008 \\
\hline 314 & Env & Gp120 & YRLISCNTSVITQACPKV & 58206 & 31273 & 0.943 & 0.008 \\
\hline 315 & Env & Gp120 & SVITQACPKVSFEPIPIH & 61011 & 32871 & 0.944 & 0.034 \\
\hline 320 & Env & Gp120 & TNVSTVQCTHGIRPW & 341587 & 34640 & 0.820 & 0.034 \\
\hline 355 & Env & Gp120 & VAPTKAKRRWQREKRAV & 161602 & 34117 & 0.870 & 0.042 \\
\hline 399 & Env & Gp41 & VIEWQRACRAILHIPRR & 388089 & 34640 & 0.812 & 0.026 \\
\hline 405 & Vif & - & VKHHMYISGKAKGWFYRH & 16458 & 37237 & 1.084 & 0.021 \\
\hline 406 & Vif & - & GKAKGWFYRHHYESTHPR & 16458 & 37237 & 1.084 & 0.022 \\
\hline 424 & Vif & - & TKLTEDRWNKPQKTKGHR & 10319 & 36434 & 1.137 & 0.014 \\
\hline
\end{tabular}

* PR values in bold indicate PR > 1, i.e. OLP-responses seen more frequently in individuals with reduced viral loads 


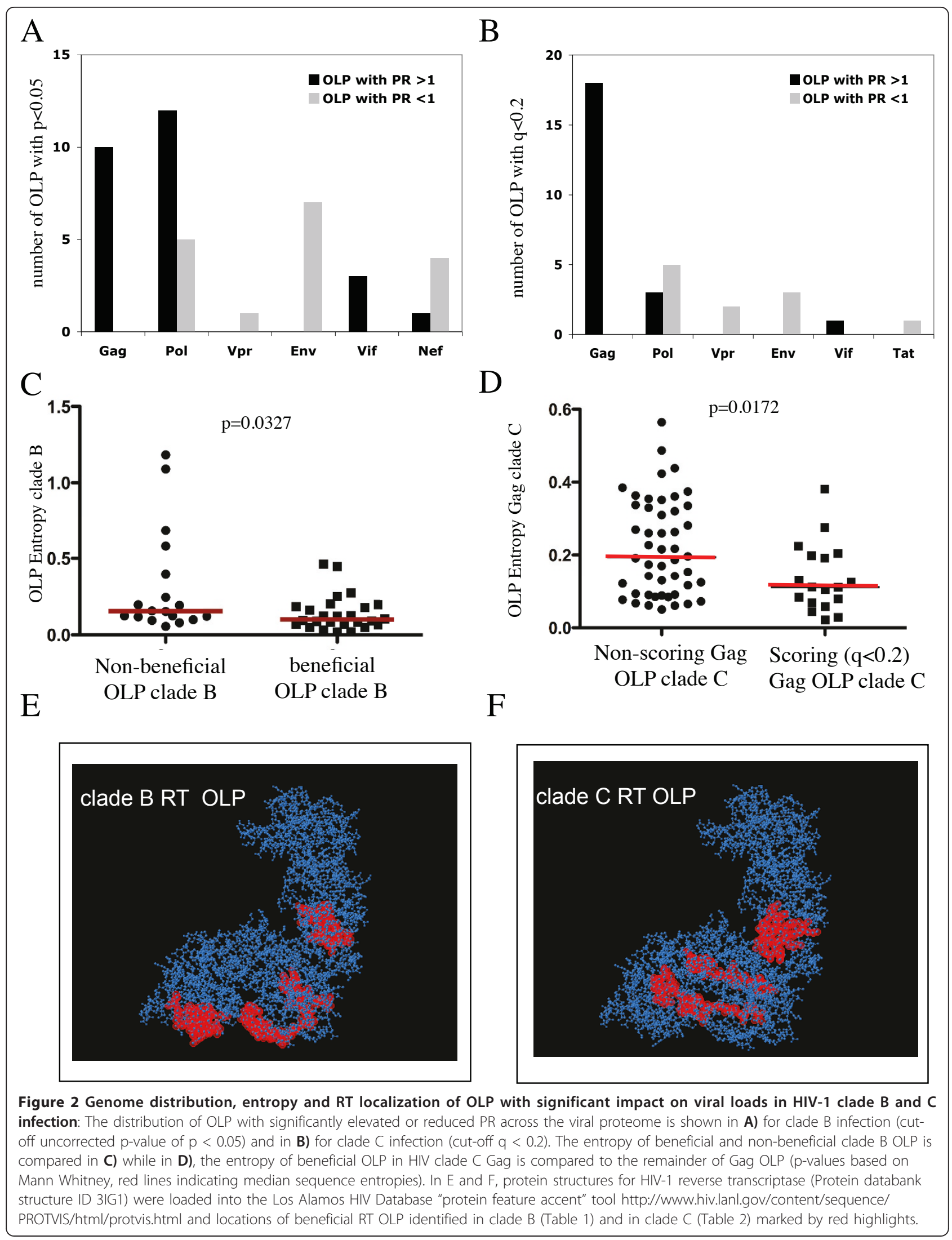


Table 2 Beneficial and non-beneficial OLP identified in Durban clade $C$ cohort $(q<0.2)$

\begin{tabular}{|c|c|c|c|c|c|c|c|c|}
\hline OLP \# & Protein & Sub-unit & $\begin{array}{c}\text { OLP clade C } \\
\text { consensus } \\
\text { sequence }\end{array}$ & $\begin{array}{l}\text { Median viral } \\
\text { load in OLP } \\
\text { responders }\end{array}$ & $\begin{array}{c}\text { Median viral } \\
\text { load in OLP } \\
\text { non-responders }\end{array}$ & $\begin{array}{c}\text { Protective Ratio } \\
\text { (PR)* }\end{array}$ & p-value & Q-value \\
\hline 3 & Gag & p17 & EKIRLRPGGKKHYMLKHL & 18,700 & 45,100 & 1.09 & 0.0002 & 0.0006 \\
\hline 6 & Gag & p17 & ASRELERFALNPGLL & 6,570 & 44,100 & 1.22 & 0.0000 & 0.0000 \\
\hline 7 & Gag & p17 & ERFALNPGLLETSEGCK & 5,270 & 43,900 & 1.25 & 0.0000 & 0.0000 \\
\hline 22 & Gag & p24 & WVKVIEEKAFSPEVIPMF & 8,360 & 42,850 & 1.18 & 0.0000 & 0.0000 \\
\hline 25 & Gag & p24 & GATPQDLNTMLNTVGGH & 24,450 & 45,200 & 1.06 & 0.0021 & 0.0263 \\
\hline 26 & Gag & p24 & NTMLNTVGGHQAAMQMLK & 5,310 & 39,600 & 1.23 & 0.0061 & 0.0766 \\
\hline 27 & Gag & p24 & GGHQAAMQMLKDTINEEA & 9,715 & 42,100 & 1.16 & 0.0015 & 0.0170 \\
\hline 29 & Gag & p24 & AAEWDRLHPVHAGPIA & 19,700 & 40,900 & 1.07 & 0.0045 & 0.0544 \\
\hline 31 & Gag & p24 & IAPGQMREPRGSDIA & 6,480 & 38,950 & 1.20 & 0.0146 & 0.1478 \\
\hline 33 & Gag & p24 & SDIAGTTSTLQEQIAWM & 11,650 & 40,900 & 1.13 & 0.0025 & 0.0318 \\
\hline 37 & Gag & p24 & WIILGLNKIVRMYSPVSI & 9,360 & 44,100 & 1.17 & 0.0004 & 0.0018 \\
\hline 39 & Gag & p24 & SILDIKQGPKEPFRDYV & 2,630 & 38,250 & 1.34 & 0.0182 & 0.1838 \\
\hline 41 & Gag & p24 & YVDRFFKTLRAEQATQDV & 22,150 & 44,100 & 1.07 & 0.0020 & 0.0263 \\
\hline 42 & Gag & p24 & LRAEQATQDVKNWMTDTL & 16,480 & 40,900 & 1.09 & 0.0078 & 0.0935 \\
\hline 55 & Gag & p15 & HIARNCRAPRKKGCWK & 7,550 & 39,700 & 1.19 & 0.0092 & 0.1047 \\
\hline 59 & Gag & p15 & RQANFLGKIWPSHKGR & 9,840 & 42,200 & 1.16 & 0.0046 & 0.0539 \\
\hline 60 & Gag & p15 & GKIWPSHKGRPGNFLQSR & 6,130 & 39,700 & 1.21 & 0.0066 & 0.0799 \\
\hline 63 & Gag & p15 & TAPPAESFRFEETTPAPK & 6,040 & 38,950 & 1.21 & 0.0093 & 0.1020 \\
\hline 116 & Tat & Tat & TKGLGISYGRKKRRQRRS & 109,000 & 36,700 & 0.91 & 0.0033 & 0.0410 \\
\hline 178 & Pol & RT & FWEVQLGIPHPAGLKKKK & 258,000 & 37,300 & 0.84 & 0.0033 & 0.0384 \\
\hline 181 & Pol & RT & LDVGDAYFSVPLDEDFRK & 7,100 & 38,950 & 1.19 & 0.0186 & 0.1832 \\
\hline 190 & Pol & RT & RAQNPEIVIYQYMDDLYV & 84,900 & 34,700 & 0.92 & 0.0043 & 0.0555 \\
\hline 199 & Pol & RT & TVQPIQLPEKDSWTVNDI & 6,700 & 38,300 & 1.20 & 0.0198 & 0.1926 \\
\hline 216 & Pol & RT & QKIAMESIVIWGKTPKFR & 18,150 & 43,000 & 1.09 & 0.0026 & 0.0317 \\
\hline 239 & Pol & RT & QVDKLVSSGIRKVLFL & 373,200 & 37,700 & 0.82 & 0.0205 & 0.1937 \\
\hline 253 & Pol & Int & PAETGQETAYFILKLAGR & 92,800 & 35,400 & 0.92 & 0.0082 & 0.0954 \\
\hline 265 & Pol & Int & AVFIHNFKRKGGIGGYSA & 63,650 & 33,800 & 0.94 & 0.0178 & 0.1826 \\
\hline 283 & Vpr & - & GLGQYIYETYGDTWTGV & 78,000 & 35,600 & 0.93 & 0.0126 & 0.1302 \\
\hline 284 & Vpr & - & ETYGDTWTGVEALIRIL & 85,050 & 35,200 & 0.92 & 0.0099 & 0.1034 \\
\hline 312 & Env & Gp120 & YALFYRLDIVPLNENNSSEY & 270,000 & 37,700 & 0.84 & 0.0208 & 0.1915 \\
\hline 365 & Env & Gp41 & GIKQLQTRVLAIERYLK & 151,000 & 34,700 & 0.88 & 0.0001 & 0.0002 \\
\hline 393 & Env & Gp41 & LLGRSSLRGLQRGWEALKYL & 750,000 & 37,450 & 0.78 & 0.0007 & 0.0041 \\
\hline 417 & Vif & - & CFADSAIRKAILGHIV & 1,110 & 38,200 & 1.50 & 0.0178 & 0.1891 \\
\hline
\end{tabular}

* PR values in bold indicate PR > 1, i.e. OLP-responses seen more frequently in individuals with reduced viral loads

$2 \mathrm{E}$ and $2 \mathrm{~F}$ ). This suggests that despite differences in response patterns between ethnicities and clades, viruses from both clades may be vulnerable to responses targeting the same structural regions of at least some of their viral proteins.

Increased breadth of responses against beneficial OLP is associated with decreasing viral loads, independent of Gag-specificity or the presence of protective HLA class I alleles

To assess whether individuals targeting more than one beneficial OLP profit from a greater breadth of responses to these targets, subjects in both cohorts were stratified by the number of responses to beneficial OLP and their viral loads compared. In both cohorts, negative correlations between the number of responses to beneficial OLP and viral loads were observed $(\mathrm{p}<0.0001, \mathrm{r}=$ -0.33 for Lima; $\mathrm{p}<0.0001, \mathrm{r}=0 .-25$ for Durban; data not shown), suggesting that there is a cumulative benefit of responses to these particularly effective targets. Similarly, when individuals in the clade $\mathrm{C}$ cohort were grouped based on mounting 1-2, 3-4 or five and more beneficial OLP responses, a gradual reduction in median viral loads was seen. This reduction was close to 20 -fold when 5 or more of the 22 beneficial OLP were targeted (median viral load 5,210 copies/ml) compared to individuals without a response $(98,800 \mathrm{copies} / \mathrm{ml}$, Figure 3A). Importantly, this observation was not driven only by individuals expressing HLA class I alleles associated with relative control of viral replication (including HLA- 


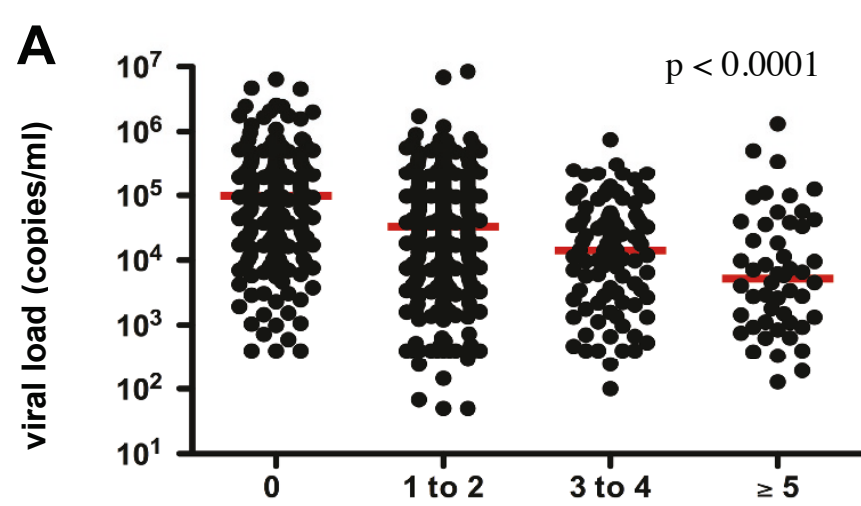

Number of responses per individual to OLP with $P R>1$ and $q<0.2$

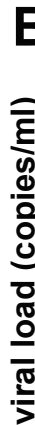
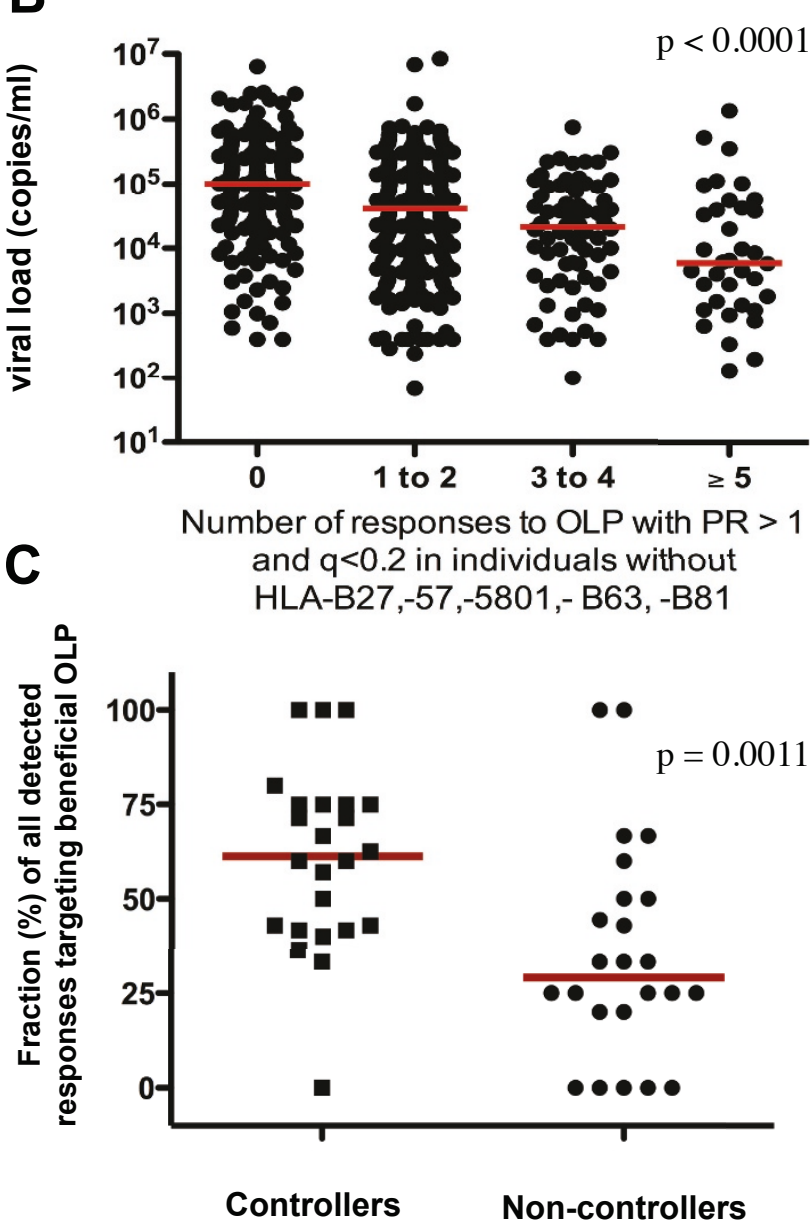

Figure 3 Increased breadth of responses to beneficial OLP results in gradually reduced viral loads and is independent of cohort and HLA-B27, -57, -B58, -B81 and -B63. (A) The number of responses to beneficial OLP in the clade C cohort in Durban was determined for each individual and compared to viral loads. An increased breadth of responses to the 22 beneficial OLP was associated with reduced viral loads (ANOVA, $p<0.0001$ ). (B) This association remained equally stable after removing all individuals expressing known beneficial HLA allele (HLA-B27, $-B 57,-B 5801,-B 63,-B 81$ ) from the analysis (ANOVA, $p<0.0001$ ). (C) The set of 26 beneficial and 17 non-beneficial OLP identified in the clade B infected cohort in Lima, Peru was tested in a second clade B infected cohort in Barcelona. HIV controllers showed a significantly higher focus of responses on the 22 beneficial OLP (61\% of all responses to the 43 OLP) while non-controllers reacted predominantly with the non-beneficial OLP (only 29\% of all responses targeting beneficial OLP). The Barcelona cohort did not included subject expressing any HLA allele previously associated with relative control of HIV-1 $(p=0.0011$, Mann Whitney). 
B27, - B57, $-\mathrm{B}^{*} 5801,-\mathrm{B} 63$ and $-\mathrm{B} 81$ ) as their exclusion still showed a strong association between increased breadth of responses to beneficial OLP and a gradual suppression of viremia (Figure $3 \mathrm{~B}$ ). This was further supported when translating the clade B data from Peru to a second clade B infected cohort in Barcelona, Spain where HIV-1 controllers also mounted a significantly greater proportion of their responses to the beneficial Peruvian OLP compared to the HIV-1 non-controllers (61\% vs. $29 \%, p=0.0011$; Figure $3 C$ ); this despite the fact that the Barcelona cohort was genetically different and excluded individuals expressing HLA-B27, -B57, -B58 and B63. Thus, despite the frequent targeting of Gag and the inclusion of individuals expressing HLA alleles such as HLA-B*5701 and -B*5801 in the two larger clade $B$ and $C$ cohorts, the present data identify regions of the viral genome that serve as the targets of an effective host $\mathrm{T}$ cell response, largely independent of the presence of HLA alleles known to influence HIV-1 viral replication.

\section{PR-values are mediated by individuals with broad HLA heterogeneity}

To further assess the contribution of specific HLA class I alleles on the PR of individual OLP, the statistically significant OLP in the clade $C$ cohort were further analyzed. In a first step, median viral loads in the OLPresponder and non-responder groups were compared after excluding individuals with specific HLA class I alleles. If the statistical significance of the comparison was lost, the excluded HLA class I allele was assumed to have significantly contributed to the initially observed elevated or reduced PR value and to restrict a potential CTL epitope in that OLP. In a second step, a "Hepitope" analyses http://www.hiv.lanl.gov/content/immunology/ hepitopes was conducted to identify HLA class I alleles overrepresented in the OLP responder group; providing an alternative approach to identify specific epitopes that may contribute to relative viral control. Together, the two strategies permit to estimate the HLA diversity in the OLP responders and to identify the most likely alleles that restrict the epitope-specific responses to the OLP. Both are important measures when determining the relative usefulness of a selected beneficial OLP in a potential immunogen sequence as it should provide broad HLA coverage. The data from these analyses are summarized for beneficial and non-beneficial OLP in Table 3 and 3, respectively. The results demonstrate that with a few exceptions, for each OLP, several HLA alleles appeared to be mediating the observed effects as their removal caused the statistical significance to be lost. However, for the most frequent HLA class I alleles, the loss of significance may be due to a reduction in sample size rather than the actual allele, since the exclusion of many allele carriers could reduce the number of OLP responders (and non-responders) sufficiently to lose statistical power. The "Hepitope" analysis controlled for this effect and confirmed the obtained results, strongly indicating that responses to beneficial OLP were mediated by responder populations with heterogeneous HLA allele distributions.

\section{Effects of T cell specificity on in vivo viral load are at least as strong as those associated with host HLA genetics}

To assess whether specific response patterns and/or HLA combinations could be identified that mediated synergistic or superior control of viral infection in clades $\mathrm{B}$ and $\mathrm{C}$, multivariate combined regression analysis was conducted on either OLP only, HLA only or the combination of OLP and HLA variables [41-43]. The OLPonly analysis for Lima identified 7 OLP of which 4 were associated with lower median viral loads and 3 with increases in viral loads, respectively (Table 4). Targeting at least one of these beneficial clade B OLP was associated with significantly reduced viral loads (median 11, 079 copies $/ \mathrm{ml}$ ) compared to the subjects who did not target any of these four OLP (median 52, 178 copies $/ \mathrm{ml}$; $\mathrm{p}<0.0001$, Figure 4A). As seen in the univariate analysis (Figure 2C), the four beneficial OLP emerging from the Lima FASS analysis were more conserved than the rest of the OLP (median entropy 0.0759 vs. $0.1649, \mathrm{p}=$ $0.0267)$ or the three non-beneficial OLP (0.0759 vs. $0.1228, \mathrm{p}=0.0571$, data not shown). In contrast to OLP-only FASS analysis, only one HLA allele (HLAC04) emerged from the HLA-only multivariate analysis. The analysis for the combined variables (OLP and HLA) controlled for the potential bias in this result due to more OLP variables $(n=389)$ than HLA $(n=146)$ being included in the statistical tests; yet still identified more OLP variables $(n=9)$ than HLA class I alleles ( $n$ $=3$ ). In addition, the relative co-efficients of these associations were stronger for the OLP than the HLA variables, suggesting that $\mathrm{T}$ cell specificity influenced viral loads to at least the same degree as host HLA class I genetics. Of note, the identified OLP and HLA variables did not reflect responses to known optimal CTL epitopes, as none of the OLP contained described epitope (s) restricted by any of the identified HLA alleles [44].

Results from the clade $\mathrm{C}$ cohort in Durban confirmed the clade B findings in Lima as the FASS analyses identified 16 OLP but only 8 HLA variables that had an impact on the individual viral loads. As in Lima, the impact of OLP specificity was at least as strong than HLA genotype (trend for higher coefficients for OLP than HLA; data not shown, $\mathrm{p}>0.05)$. In addition, targeting at least one of the eight beneficial OLP in Durban was associated with strongly reduced viral loads ( $\mathrm{c}$ 
Table 3 Impact of HLA alleles on the statistical significance of observed PR values (clade C OLP)

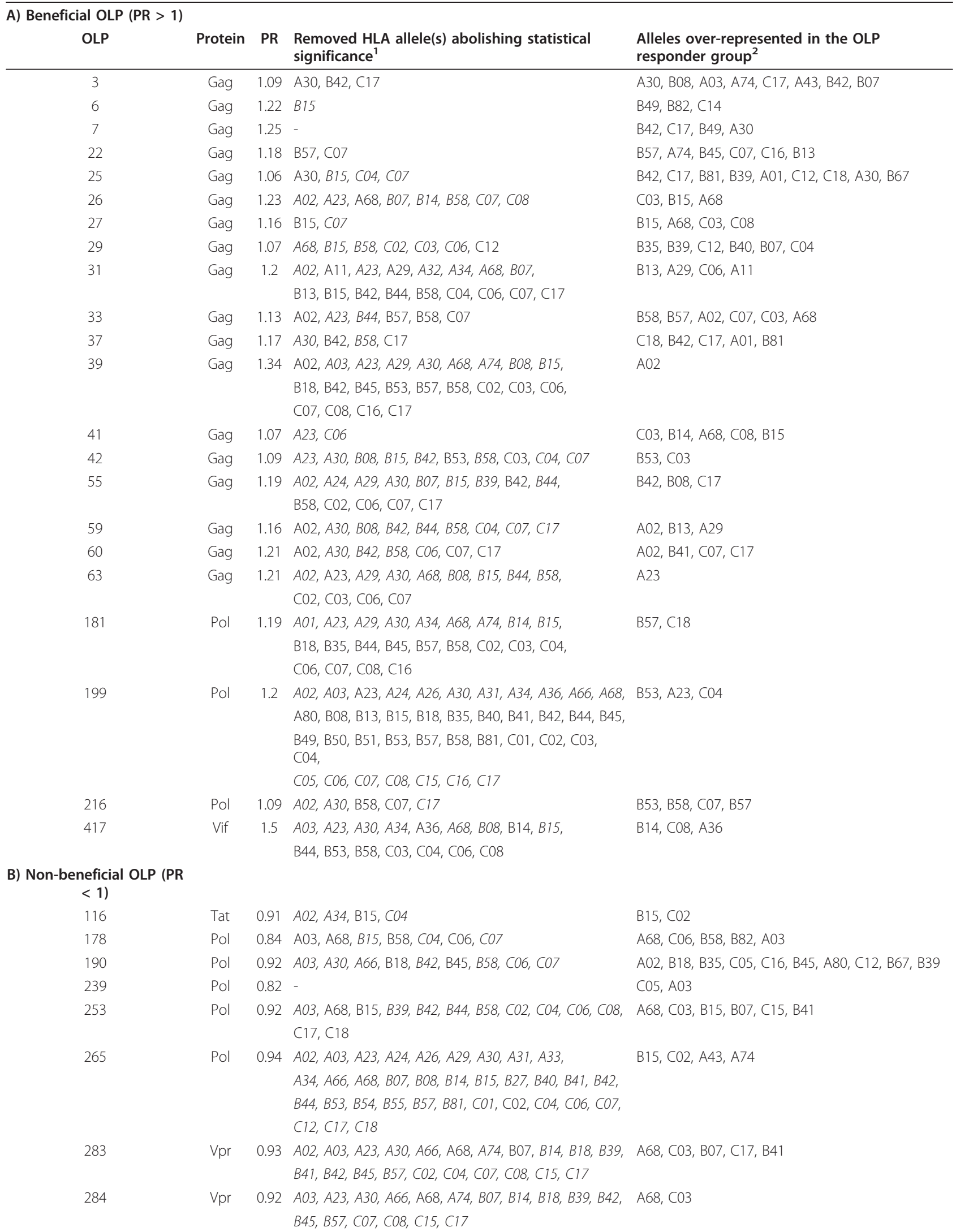


Table 3 Impact of HLA alleles on the statistical significance of observed PR values (clade C OLP) (Continued)

\begin{tabular}{lllll}
\hline 312 & Env & 0.84 & - & B08, C07 \\
365 & Env & 0.88 & B58, C06 & C06, B58, A43, B45, C16, A66 \\
393 & Env & 0.78 & A30, B58, C06 & A31, C06, B45 \\
\hline
\end{tabular}

1) in italics HLA alleles that do not emerge from the Hepitope analysis 2) cut-off in Hepitope analyses for $p<0.05$, alleles sorted according to strength of association

0.0001, Figure 4B). This effect was, as in the univariate analysis, additive for more than one response ( $\mathrm{p}<$ 0.0001 , Figure 4C) and included OLP that were, aside from Gag, located in Pol and Vif. Also, the combined (OLP and HLA) analysis suggests the effect of OLP specificity on viral loads to be at least as strong as HLA genetics as 8 OLP and 7 HLA variables were identified. This especially since among the 7 HLA alleles, two (HLA-B57 and HLA-A74) are expressed in linkage disequilibrium [47], further reducing the number of HLA variables with a significant impact on viral loads.

\section{Responses to beneficial OLP are of higher functional avidity and suppress viral replication in vitro more effective than responses to non-beneficial OLP}

Functional avidity and the ability to suppress in vitro viral replication have emerged as two potentially crucial parameters of an effective CTL response against HIV-1 [23-29]. To assess this potential functional characteristic of beneficial CTL populations, we determined the functional avidity of responses to the four beneficial OLP located in Gag p24, a region that has been most consistently associated with eliciting relatively protective CTL responses. As 18 mer peptides are suboptimal test peptides to determine functional avidity, 10 mer overlapping peptide sets were synthesized to cover the four beneficial OLP and all detected responses were titrated. The SD50\% was determined for a comparable numbers of responses detected in controllers ( $\mathrm{n}=21$ responses) and non-controllers ( $\mathrm{n}=24$ responses) and showed a statistically significant difference between the two groups (median 3, 448 ng/ml vs. 25, 924 ng/ml, p = 0.0051, Figure 5A). This reduced avidity in HIV non-controllers to beneficial OLP could possibly explain why HIV-1 noncontrollers did not control their in vivo viral replication despite targeting these regions in some instances and with responses of comparable magnitude as HIV controllers (278 SFC vs 305 SFC $/ 10^{6}$ PBMC, $\mathrm{p}=0.55$, data not shown).

To more directly assess whether responses to beneficial OLP were of particularly high functional avidity, regardless of HIV controller status, we determined SD50\% of responses to 17 optimal epitopes from beneficial, neutral and non-beneficial OLP (Figure 5B). Median epitope-specific SD50\% were determined from an average of 7 titrations per epitope and compared to the
OLP specific PR. A strongly significant, negative association between the PR and the SD50\% was noted ( $\mathrm{p}=$ $0.002, r=-0.69)$, indicating that beneficial OLP are targeted by high-avidity responses. To control for interindividual differences due to disease status and viral load, we identified 10 individuals who targeted optimal epitopes in beneficial and non-beneficial OLP and determined their functional avidity. As in the cross-sectional analysis before, this matched comparisons showed in all cases a higher functional avidity for the epitopes located in the beneficial OLP compared to the responses targeting non-beneficial OLP (Figure $5 \mathrm{C}, \mathrm{p}=0.0020$ ). Lastly, to relate the higher functional avidity to potential superior anti-viral effects in vivo, the ability to inhibit in vitro viral replication was assessed in three individuals who mounted robust responses against both beneficial and non-beneficial OLP. The in vitro inhibition assay first developed by Yang et al [48], was modified so that the NL4-3 based test virus contained a single nucleotide mutation in Nef (M20A) that blocks the Nef-mediated down-regulation of HLA class I molecules as well as two mutations in the integrase gene that mediate Raltegravir-resistance to permit the suppression of potentially replicating autologous virus in the assay. Indeed, CTL specific for the beneficial $\operatorname{OLP}(\mathrm{s})$ were up to $2 \operatorname{logs}$ more effective inhibiting viral replication than CTL targeting non-beneficial OLP (Figure 5D), in line with recent data demonstrating different suppressive ability of HIV-1 specific CTL populations targeting Gag and Env-derived epitopes [24]. Although the in vitro inhibition assays were limited to few individuals with suitable response patterns, these data together with the results from the extensive titration assays in Figure $5 \mathrm{~B}$ and $5 \mathrm{C}$ indicate that responses to beneficial OLP are of particularly high functional avidity and inhibit in vitro viral replication more effectively than responses to non-beneficial OLP. Of note, higher avidity responses to beneficial OLP compared to non-beneficial OLP were seen in all 10 tested individuals, ruling out that inter-individual variability in viral loads, duration of infection and HIV disease status could have biased the analyses.

\section{Conclusions}

Defining functional correlates of HIV-1 immune control is critical to the design of effective immunogens. $\mathrm{T}$ cell responses to specific $\mathrm{HIV}-1$ proteins and protein- 
Table 4 Multivariate analysis of OLP and HLA variables for clade B and C cohorts

\begin{tabular}{|c|c|c|c|c|c|}
\hline \multicolumn{3}{|c|}{ OLP variables only (Lima, clade B) } & \multicolumn{3}{|c|}{ OLP variables only (Durban, clade C) } \\
\hline & change viral load (co-efficient) * & p-value & & change viral load (co-efficient) * & p-value \\
\hline Beneficial & & & $\underline{\text { Beneficial }}$ & & \\
\hline OLP.6 & -0.4591 & 0.0008 & OLP.7 & -0.6256 & 0 \\
\hline OLP.31 & -1.4055 & 0.0002 & OLP.21 & -0.6663 & 0 \\
\hline OLP.171 & -2.5981 & 0 & OLP.22 & -0.4926 & 0.0006 \\
\hline \multirow[t]{2}{*}{ OLP.276 } & -1.127 & 0.0007 & OLP.25 & -0.2822 & 0.0002 \\
\hline & & & OLP.27 & -0.4719 & 0.0053 \\
\hline Non-beneficial & & & OLP.33 & -0.3396 & 0.0024 \\
\hline OLP.76 & 0.2486 & 0.0067 & OLP.398 & -1.8179 & 0.0027 \\
\hline OLP.306 & 3.2968 & 0.0001 & OLP.417 & -1.6535 & 0.0008 \\
\hline \multirow[t]{10}{*}{ OLP.411 } & 1.3329 & 0.012 & & & \\
\hline & & & Non-beneficial & & \\
\hline & & & OLP.38 & 0.9045 & 0.0022 \\
\hline & & & OLP.84 & 0.1947 & 0.0091 \\
\hline & & & OLP.116 & 0.6156 & 0.0039 \\
\hline & & & OLP.183 & 0.661 & 0.0013 \\
\hline & & & OLP.224 & 0.2508 & 0.0036 \\
\hline & & & OLP.265 & 0.5782 & 0 \\
\hline & & & OLP.365 & 0.4911 & 0.0009 \\
\hline & & & OLP.393 & 1.2624 & 0.0013 \\
\hline \multicolumn{3}{|c|}{ HLA variables only (Lima, clade B) } & \multicolumn{3}{|c|}{ HLA variables only (Durban, clade C) } \\
\hline Non-beneficial & & & $\underline{\text { Beneficial }}$ & & \\
\hline \multirow[t]{9}{*}{ HLA-C0401 } & 0.35652 & 0.00024 & HLA-A74 & -0.3553 & 0.0025 \\
\hline & & & HLA-B13 & -0.6443 & 0.0004 \\
\hline & & & HLA-B57 & -0.5195 & 0.0007 \\
\hline & & & HLA-B81 & -0.3619 & 0.0015 \\
\hline & & & HLA-C12 & -0.6544 & 0.0001 \\
\hline & & & Non-beneficial & & \\
\hline & & & HLA.B.15 & 0.2506 & 0.0012 \\
\hline & & & HLA.B.18 & 0.5521 & 0.0005 \\
\hline & & & HLA.C.6 & 0.3958 & 0 \\
\hline \multicolumn{3}{|c|}{ HLA and OLP variables together (Lima) } & \multicolumn{3}{|c|}{ HLA and OLP variables together (Durban) } \\
\hline Beneficial & & & Beneficial & & \\
\hline OLP.6 & -0.5792 & 0 & OLP.6 & -0.4798 & 0.0023 \\
\hline OLP.31 & -1.1607 & 0.0005 & OLP.7 & -0.4528 & 0.0015 \\
\hline OLP.171 & -2.7948 & 0 & OLP.27 & -0.4676 & 0.0049 \\
\hline \multirow[t]{2}{*}{ OLP.276 } & -0.9609 & 0.0011 & OLP.59 & -0.4196 & 0.0115 \\
\hline & & & OLP.417 & -1.387 & 0.0041 \\
\hline$\underline{\text { Non-beneficial }}$ & & & $\underline{\text { Non-beneficial }}$ & & \\
\hline OLP.2 & 0.3945 & 0.018 & OLP.148 & 2.5215 & 0.0029 \\
\hline OLP.237 & 0.7211 & 0.0035 & OLP.183 & 0.6108 & 0.0023 \\
\hline OLP.288 & 1.5537 & 0.0016 & OLP.393 & 1.1442 & 0.0023 \\
\hline OLP.311 & 0.7197 & 0.0091 & & & \\
\hline \multirow[t]{2}{*}{ OLP.411 } & 1.5306 & 0.0024 & Beneficial & & \\
\hline & & & HLA-A74 & -0.3744 & 0.0007 \\
\hline$\underline{B e n e f i c i a l}$ & & & HLA-B57 & -0.4887 & 0.0007 \\
\hline \multirow[t]{2}{*}{ HLA-B1502 } & -1.4688 & 0.0164 & HLA-B81 & -0.3859 & 0.0004 \\
\hline & & & $\mathrm{HLA}-\mathrm{C} 12$ & -0.6003 & 0.0002 \\
\hline Non-beneficial & & & Non-beneficial & & \\
\hline HLA-B0801 & 0.66 & 0.0049 & HLA-B15 & 0.2797 & 0.0001 \\
\hline \multirow[t]{2}{*}{ HLA-C0401 } & 0.2894 & 0.0006 & HLA-B18 & 0.5316 & 0.0003 \\
\hline & & & HLA-B49 & 0.9713 & 0.0007 \\
\hline
\end{tabular}

${ }^{*}$ negative co-efficient values indicate reduction in median viral loads 


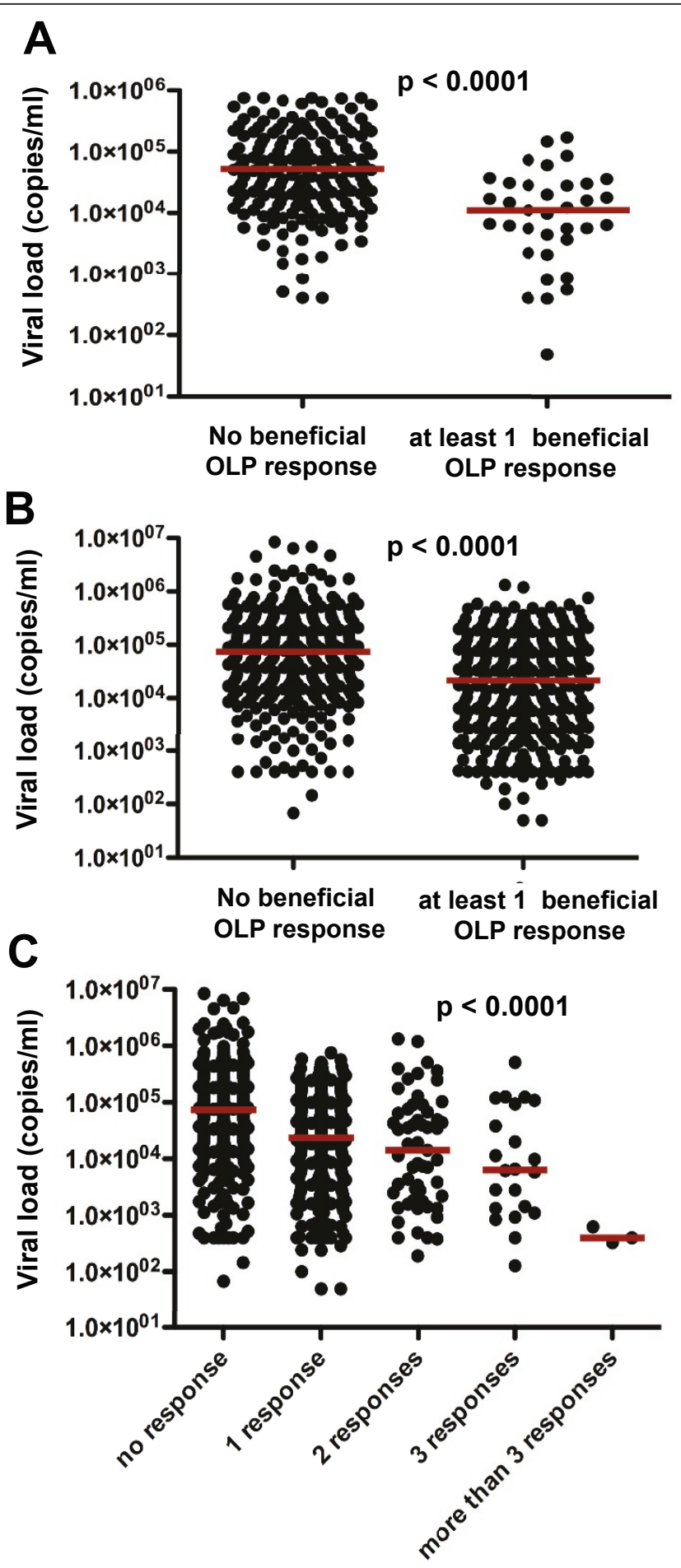

Figure 4 Responses to OLP identified in multi-variate analysis are associated with reduced viral loads: Response patterns and HLA class I genetics in the clade B cohort in Lima and clade C cohort in Durban were subjected to FASS multivariat analysis [41-43]. Viral loads in individuals mounting zero vs. at least one response to beneficial OLP identified by the FASS multi-variate analysis were compared for (A) the Lima clade B cohort and the (B) Durban clade C cohort. The larger data set for the clade C cohort allowed for a further stratification of the responder group by increasing numbers of targeted OLP emerging from the FASS analysis (C). A gradually declining median viral load in relation to an increasing breadth of these responses was seen (ANOVA, $p<0.0001$ ). 

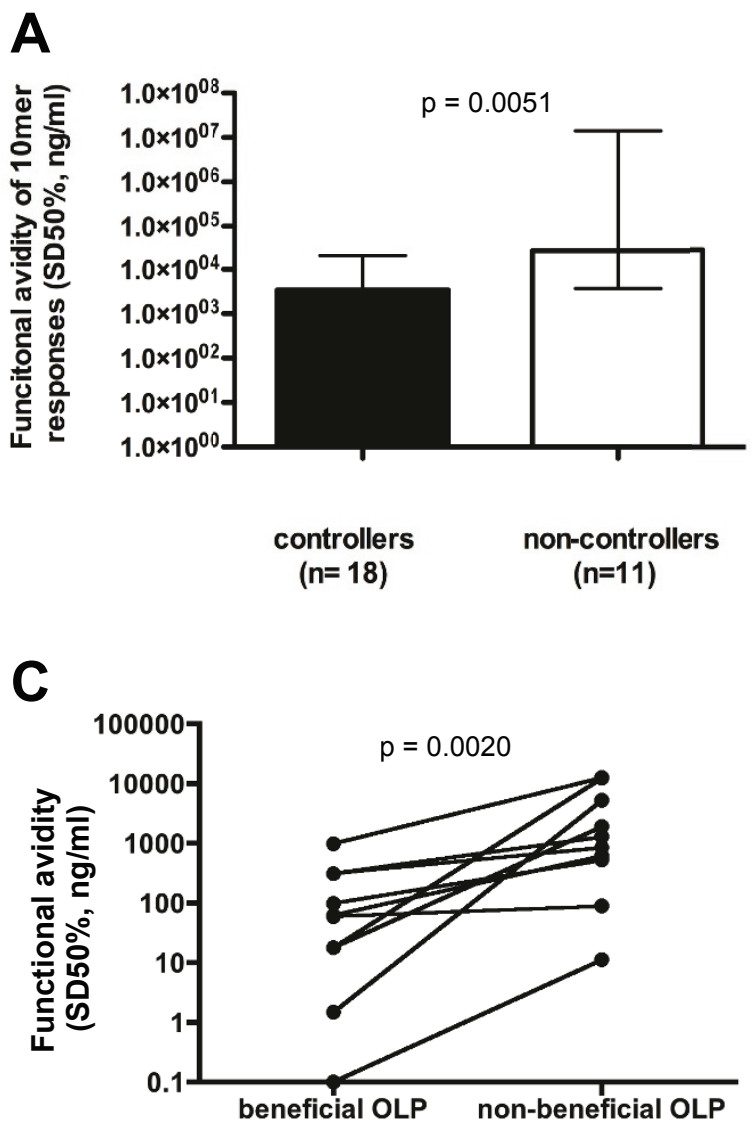

B

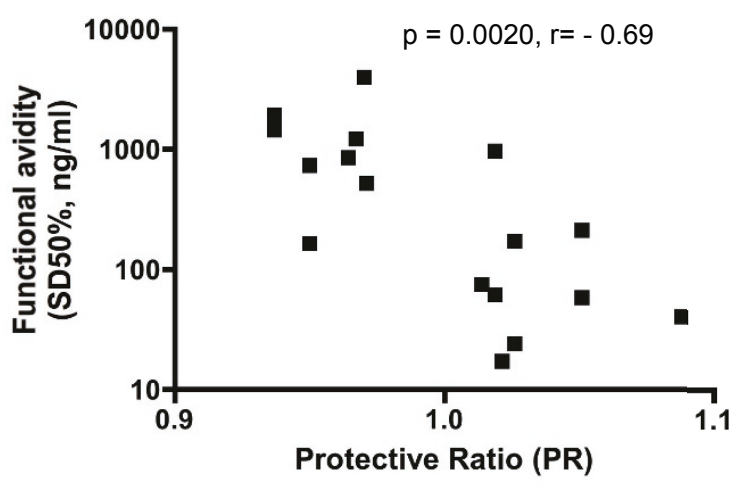

D

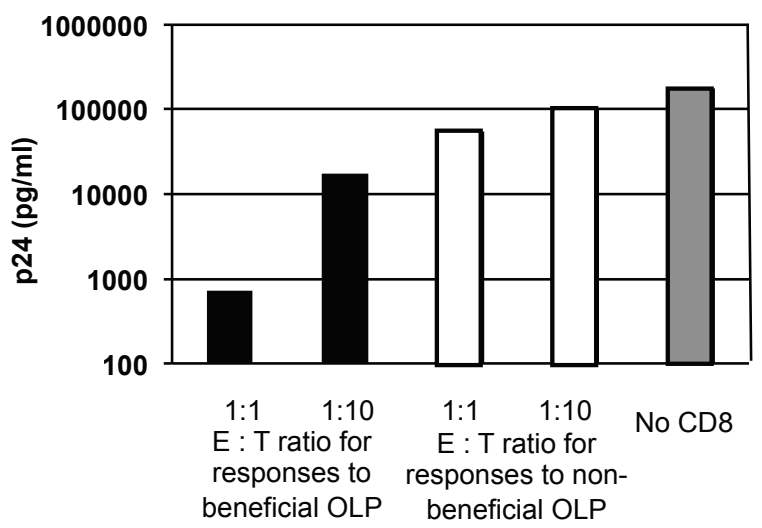

Figure 5 Responses to beneficial OLP are of higher functional avidity and suppress in vitro viral replication more effectively. (A) Responses to the four beneficial OLP located in HIV-1 clade B Gag p24 were retested using a peptide set of 10 mers overlapping by 9 residues. A total of 21 responses in HIV-1 controllers and 24 responses in HIV-1 non-controllers were titrated and the SD50\% compared between the two groups, showing a significantly higher functional avidity in the controllers ( $p=0.0051$, Mann Whitney). (B) Responses to 17 different optimally defined CTL epitopes located in beneficial, neutral and non-beneficial OLP were titrated in samples from 78 HIV infected individuals with variable viral load and disease status. The median SD50\% (ng/ml) was defined for each epitope and compared to the OLP-specific protective ratio (Spearman Rank test, $p=0.0020$ ). (C) Ten individuals who mounted responses to well-defined optimal CTL epitopes located in beneficial as well as in non-beneficial clade B OLP were identified and their responses titrated. The SD50\% for responses detected in the same individual were compared (Wilcoxon matched pairs test, $p=0.0039$ ). (D) In-vitro viral replication inhibition assays [48] were performed using a Nef modified and Raltegravir resistant test virus and purified CTL effector populations from the same individual targeting beneficial and non-beneficial OLP. One representative experiment of three assays conducted in different individuals is show. Levels of Gag p24 were determined after 4 days of coculture of effector cells and auologous CD4 T cells used as target cells. Target cells were stimulated 3 days prior with dual-specific anti-CD3/8 $\mathrm{mAb}$ and infected at a $\mathrm{MOI}$ of 0.1 . The negative control contained wells with target cells only ("no CD8").

subunits have been associated before with relatively superior viral control in vivo $[14,16,49]$, but evidence from recent clinical trials suggests that including maximal immunogen content into various vectors does not necessarily induce more effective CTL responses [50,51]. In fact, it has been argued that the existence of potential "decoy" epitopes may divert an effective CTL response towards variable and possibly less effective targets in the viral genome [52]. Thus, the definition of a minimal yet sufficient immunogen sequence that can elicit CTL responses in a broad HLA context is urgently needed. Thereby, focusing vaccine responses on conserved regions could help induce responses towards mutationally constrained targets and provide the basis for protection from heterologous viral challenge.

We present here the results of an extensive analysis that included more than 950 HIV-1 infected individuals with diverse HLA genotypes, from three different continents and including clade $\mathrm{B}$ and $\mathrm{C}$ infections. In both, the analysis in clade B in Lima and clade C in Durban, 
individual OLP were identified that are predominantly targeted by individuals with reduced or elevated viral loads, although the different size of the cohorts required different statistical approaches for their identification. In general, most of these OLP were among the more frequent targets in the HIV proteome, possibly due to both, the need for sizable responder groups to achieve statistical significance in the viral loads comparison as well as the high epitope density in these OLP. The identified OLP were frequently located in HIV-1 Gag and Pol, but rarely in the more variable proteins such as Env and Nef. With one exception, Nef and Env featured only non-beneficial OLP, thus arguing against their inclusion, at least as full proteins, in a CTL immunogen sequence [16]. In addition, in both cohorts, the Vif protein yielded few, yet exclusively beneficial OLP, which may warrant a renewed look at the inclusion of regulatory proteins in vaccine design $[53,54]$. Also common to both clades, (and despite the wide scatter possibly due to the inclusion of less-frequently targeted OLP), an negative correlation between sequence entropy and PR was observed providing strong rationale for vaccine approaches that focus on conserved viral regions where $T$ cell escape may be complicated by structural constrains [55]. This was particularly evident in the clade $\mathrm{C}$ cohort, where even within the relatively conserved Gag protein, a lower entropy was seen for the beneficial OLP compared to the remainder of the OLP spanning the protein. On the other hand, while beneficial and non-beneficial OLP showed a significant difference in their median entropy in the clade B cohort, this comparison was not significant in the clade $\mathrm{C}$ cohort. It is possible that the immunogen sequence, designed in 2001, did not optimally cover the circulating viral population in Durban throughout the enrollment period (until 2006), leading to missed responses particularly in the more variable segments of the virus $[32,56]$. The study may have thus failed to identify beneficial as well as non-beneficial OLP in the more variable genes of HIV. This should have preferentially affected highly variable OLP due to a more frequent mismatch between autologous viral sequence and in vitro test set in these regions. However, even if scoring as beneficial OLP, such high-entropy OLP may from an immunogen-design point of view be of less interest as they would possible contribute only little to protection from heterologous viral challenge. It needs however also to be considered that the OLP-specific entropy values are based on variable numbers of sequences in the Los Alamos HIV database covering the different OLP, introducing potential further bias into these analyses, particularly for less covered proteins such as Vpu and other viral protein products. Such differences between autologous viral sequences and in vitro test sets may also have impacted the assessment of functional avidities. These determinations included responses in the same individual towards epitopes located in beneficial and non-beneficial OLP; with the former overall being more conserved. Thus, the higher functional avidity towards epitopes located in beneficial OLP could be biased by the higher chance that these epitopes matched the autologous viral sequence compared to epitopes located in non-beneficial OLP and which may thus have induced a more robust, avid response. Apart from covering autologous sequences, future studies will ideally also include comparable analyses in individuals identified and tested in acute infection that go on to control the infection at undetectable levels of viral replication (i.e. elite-controllers) so that the selective early emergence of responses to beneficial OLP could be linked to relative control of viral replication in chronic infection. As is, the identified beneficial responses may be particularly important to maintain low viral replication in chronic stages of infection, which in theory could be different (for instance due to more accelerated intra-individual viral evolution in variable genes) from responses determining viral set point during acute infection. However, the existing HLA bias in such cohorts and the small number of responses identified during earliest stages of infection may make such analyses a formidable undertaking that will require large numbers of individuals to be tested longitudinally.

A broadly applicable $\mathrm{T}$ cell immunogen sequence should include $\mathrm{T}$ cell targets restricted by a wide array of HLA class I alleles. Although broad representation of HLA-B alleles may be particularly important in this regard, emerging data on the effects HLA-C alleles in these cohorts may warrant a broad HLA-C representation as well $[2,47,57]$. In the present study, the 26 beneficial OLP from Lima and the 22 beneficial OLP from Durban covered 26 described, optimally defined CTL epitopes restricted by 20 different HLA alleles for the clade B cohort and 33 epitopes presented by 34 alleles for the clade $\mathrm{C}$ cohort, respectively [44]. As this is likely to be an underestimate of the true diversity in HLA restriction (Table 2 and ref [58]), it is reasonable to predict that the inclusion of identified beneficial OLP, or even a subset thereof, could evoke potential responses in a widely diverse HLA context. This could also provide the basis for the induction of poly-specific $\mathrm{T}$ cell responses with increased breath, which the present data clearly associates with progressively lower viral loads and which emerge as a potentially important parameter from several recent vaccine studies showing superior protection from SIV challenge in animals with a broad vaccine induced responses to Gag p17 [59,60].

Recent studies have suggested a global adaptation of HIV-1 to its various host ethnicities $[4,46]$. The consequence of such adaptation has led in some cases to the 
elimination of protective CTL targets, causing a profound absence of responses to these epitopes and detrimentally changing the association between HLA allele and HIV-1 disease outcome [4]. It is thus not surprising that the two main cohorts tested here yielded only partially overlapping sets of beneficial OLP as the impact of host genetics and viral evolution in the studied populations cannot readily be overcome. In fact, given studies by Frahm et al [4], the past and current adaptation of HIV-1 to common HLA class I alleles will likely still call for somewhat population tailored vaccine approaches, especially if the immunogen sequences should be kept short to avoid regions of potentially reduced immunological value [52]. Such approaches will also profit from more extensive structural analyses that may identify specific domains of viral proteins that are or are not enriched in valuable $\mathrm{T}$ cell targets; of which the latter could possibly be ignored for the design of $\mathrm{T}$ cell immunogen sequences. Additional analyses in other genetically unrelated cohorts of HIV-1 infected individuals and studies in SIV infection may further help to guide such selective immunogen design and to understand the factors defining the effectiveness of different epitopes in mediating relative HIV-1 control. Of note, the beneficial OLP identified here, 24 in clade B and 22 in clade C infection matched other immunogen design based on conserved elements in some parts as well, i.e. of the 14 conserved elements proposed by Hanke et al, eight (57\%) overlapped at least partly with beneficial OLP identified here [61]. Similarly, among the highly conserved elements proposed by Rolland et al [52], 35\% (5/ 14) were covered by our beneficial OLP in clade B infection. These differences possibly emerge because the present analysis is based on functional $\mathrm{T}$ cell data rather than viral sequence alignments, which may not take into consideration epitope density and processing preferences of certain regions. Nevertheless, the partial overlap with these other immunogen design support the focus on conserved regions and offers the opportunity for alternative or combined vaccine approach that elicit responses to regions where the virus is and possibly remains vulnerable $[4,46,55,62]$.

Finally, we used the extensive data set available to approach the question of relative effects of host genetics (i.e. HLA) and CTL specificity on HIV-1 control. While the two factors cannot be entirely disentangled, our data suggest that CTL specificity has an at least equal if not stronger effect on viral control than HLA class I allele expression. These findings are also in line with data by Mothe et al [63] showing that targeting key regions in p24 surrounding the dominant epitopes restricted by known protective alleles (KK10 for HLA-B27 and TW10 for HLA-B57/58) in HLA-B27, -57 or B58 negative individuals is associated with significantly reduced viral loads. In addition, the presence of individuals not expressing known beneficial alleles in HIV-1 elite controller cohorts [64], further indicates that HIV-1 control is not necessarily bound to a few specific HLA class I alleles. A detailed study of the total HIV-1-specific CTL response of subjects not expressing these alleles yet effectively controlling HIV-1 can be expected to provide further and crucially needed insight into the importance of targeting specific (conserved) regions of the viral genome for HIV-1 control. Similarly, the characterization of functional attributes of these responses, including functional avidity and the ability to suppress in vitro viral replication will need to be further assessed in such individuals. Building on experimentally derived and potentially promising immunogen sequences as defined here may thus provide a suitable basis for further immunogen design and iterative clinical trials in the human setting.

\section{Acknowledgements}

This work was supported by NIH contracts N01-Al-30024 and N01-Al-15422 (CB, TA, BDW, BTK, JS), NIH-NIDCR R01 DE018925-04 (CB), grant MTM200806747-C02-00 (GG) from the Ministerio de Ciencia y Tecnología, a grant from the Instituto de Salud Carlos III (FIS PS09/00283, AL) and a grant from the Fundacio para la Investigacion y Prevencion del SIDA en España (FIPSE) \# 360737/09, CB), Spain as well as a grant from the European Community FP7 ("CUTHIVAC"). BM holds a research fellowship grant from the FIS (Rio Hortega, CM08/00020), Madrid, Spain. ZB is supported by a New Investigator Award from the Canadian Institutes of Health Research (CIHR). CB and JMP are ICREA (Institució Catalana de Recerca i Estudis Avançats) Senior Research Professors. The funders had no role in study design, data collection and analysis, decision to publish, or preparation of the manuscript.

\section{Author details}

${ }^{1}$ Irsicaixa AIDS Research Institute-HIVACAT, Badalona, Spain. ${ }^{2}$ 'Lluita contra la SIDA' Foundation, Hospital Germans Trias i Pujol, Badalona, Spain.

${ }^{3}$ Universitat Autònoma de Barcelona, Barcelona, Spain. ${ }^{4}$ Los Alamos National Laboratory, Los Alamos, NM, USA. ${ }^{5}$ Asociación Civil IMPACTA Salud y

Educacion, Lima, Peru. ${ }^{6}$ Dept. Estadística i Investigació Operativa, Universitat Politècnica de Catalunya, Barcelona, Spain. ${ }^{7}$ Ragon Institute of MGH, Harvard and MIT, Boston, MA, USA. ${ }^{8}$ Institucio Catalana de Recerca i Estudis Avançats (ICREA), Barcelona, Spain. ${ }^{9}$ MHRP, Frederick, USA. ${ }^{10}$ University of Oklahoma Medical Center, Oklahoma City, OK, USA. ${ }^{11}$ University of California, Los Angeles, CA, USA. ${ }^{12}$ Services of Immunology and Institut d'Investigacions Biomediques August Pi i Sunyer (IDIBAPS)-AIDS Research Group-HIVACAT, Hospital Clinic, Barcelona, Spain. ${ }^{13}$ British Columbia Centre for Excellence in HIV/AIDS, Vancouver, BC, Canada. ${ }^{14}$ Simon Fraser University, Burnaby, BC, Canada. ${ }^{15}$ Miscrosoft Research, Redmond, WA, USA. ${ }^{16}$ Department of Microbiology, University of Washington, Seattle, WA, USA. ${ }^{17}$ Department of Paediatrics, Nuffield Department of Medicine, Oxford, UK. ${ }^{18}$ University of KwaZulu-Natal, HIV Pathogenesis Program, DDMRI, Durban, South Africa. ${ }^{19}$ Howard Hughes Medical Institute, Chevy Chase, MD, USA. ${ }^{20}$ Santa Fe Institute, Santa Fe, NM, USA.

\section{Authors' contributions}

BM conducted cellular immune analyses, in vitro inhibition analyses and drafted the first version of the manuscript. $A L, J Z, V B$ generated the recombinant test virus, performed viral inhibition analyses and did the OLP screening of the Barcelona patients. JI and MD conducted OLP data analyses and HLA-epitope predictions. CM recruited patients and provided samples, RZ conducted and coordinated the screening of the Lima cohort subjects, SPA conducted statistical analyses and developed the multivariat analysis approach, CTB performed functional avidity analyses, MCP, JMP, OOY provided semi-genome plasmids and helped in the construction of the 
mutant test virus for inhibition analyses. MR, CJB, ZLB analyzed beneficial OLP sequences for HLA footprints associated with reduced viral fitness, MF conducted the screening of the Lima cohort subjects, JJS developed HEPITOPE tool and conducted HLA linkage analyses, WH performed HLA typing, VSM provided samples, DH performed initial multivariat analyses, TMA coordinated HLA typing and sequence analyses for the Lima cohort, JIM analyzed beneficial OLP sequences for HLA footprints and levels of sequence conservation, GG helped with the statistical analyses and the development of the multivariat analysis, PJG and BDW coordinated all OLP screenings, HLA typing and data collection in the Durban cohort, JMG and BC coordinated sample access and HLA typing in Barcelona, BTK helped with data analysis and writing of the manuscript, JS coordinated patient enrollment, ethical approval for the Lima cohort. CB conceived the study, conducted initial data analyses, and helped writing the manuscript. All authors were involved in the writing of the final manuscript and have given final approval of the version to be published.

\section{Competing interests}

The authors declare that they have no competing interests.

Received: 14 September 2011 Accepted: 7 December 2011

Published: 7 December 2011

\section{References}

1. Brander C, Frahm N, Walker B: Host immunity and viral diversity in HIV vaccine design. Current Opinion Immunol 2006, 18:1-8.

2. Kiepiela P, Leslie AJ, Honeyborne I, Ramduth D, Thobakgale C, Chetty S, Rathnavalu P, Moore C, Pfafferott K, Hilton L, Zimbwa P, Moore S, Allen T, Brander C, Addo MM, Altfeld M, James I, Mallal S, Bunce M, Barber LD, Szinger J, Day C, Klenerman P, Mullins J, Korber B, Coovadia HM, Walker BD, Goulder PJ: Dominant influence of HLA-B in mediating the potential coevolution of HIV and HLA. Nature 2004, 432(7018):769-775.

3. Frahm N, Adams S, Kiepiela P, Linde CH, Hewitt HS, Lichterfeld M, Sango K, Brown NV, Pae E, Wurcel AG, Altfeld M, Feeney ME, Allen TM, Roach T, St John MA, Daar ES, Rosenberg E, Korber B, Marincola F, Walker BD, Goulder PJ, Brander C: HLA-B63 presents HLA-B57/B58-restricted cytotoxic T-lymphocyte epitopes and is associated with low human immunodeficiency virus load. J Virol 2005, 79(16):10218-10225.

4. Frahm N, Kiepiela P, Adams S, Linde CH, Hewitt HS, Sango K, Feeney ME, Addo MM, Lichterfeld M, Lahaie MP, Pae E, Wurcel AG, Roach T, St John MA, Altfeld M, Marincola FM, Moore C, Mallal S, Carrington M, Heckerman D, Allen TM, Mullins Jl, Korber BT, Goulder PJ, Walker BD, Brander C: Control of human immunodeficiency virus replication by cytotoxic T lymphocytes targeting subdominant epitopes. Nat Immunol 2006, 7(2):173-178

5. Ngumbela KC, Day CL, Mncube Z, Nair K, Ramduth D, Thobakgale C, Moodley E, Reddy S, de Pierres C, Mkhwanazi N, Bishop K, van der Stok M, Ismail N, Honeyborne I, Crawford H, Kavanagh DG, Rousseau C, Nickle D, Mullins J, Heckerman D, Korber B, Coovadia H, Kiepiela P, Goulder PJ, Walker BD: Targeting of a CD8 T cell env epitope presented by HLAB*5802 is associated with markers of HIV disease progression and lack of selection pressure. AIDS Res Hum Retroviruses 2008, 24(1):72-82.

6. Brockman MA, Schneidewind A, Lahaie M, Schmidt A, Miura T, Desouza I, Ryvkin F, Derdeyn CA, Allen S, Hunter E, Mulenga J, Goepfert PA, Walker BD, Allen TM: Escape and compensation from early HLA-B57-mediated cytotoxic T-lymphocyte pressure on human immunodeficiency virus type $1 \mathrm{Gag}$ alter capsid interactions with cyclophilin A. J Virol 2007, 81(22):12608-12618.

7. Schneidewind A, Brockman MA, Yang R, Adam Rl, Li B, Le Gall S, Rinaldo CR, Craggs SL, Allgaier RL, Power KA, Kuntzen T, Tung CS, LaBute MX, Mueller SM, Harrer T, McMichael AJ, Goulder PJ, Aiken C, Brander C, Kelleher AD, Allen TM: Escape from the dominant HLA-B27restricted cytotoxic T-lymphocyte response in Gag is associated with a dramatic reduction in human immunodeficiency virus type 1 replication. J Virol 2007, 81(22):12382-12393.

8. Leslie A, Price DA, Mkhize P, Bishop K, Rathod A, Day C, Crawford H, Honeyborne I, Asher TE, Luzzi G, Edwards A, Rousseau CM, Mullins Jl, TudorWilliams G, Novelli V, Brander C, Douek DC, Kiepiela P, Walker BD, Goulder PJ: Differential selection pressure exerted on HIV by CTL targeting identical epitopes but restricted by distinct HLA alleles from the same HLA supertype. J Immunol 2006, 177(7):4699-4708.
9. Iversen AK, Stewart-Jones G, Learn GH, Christie N, Sylvester-Hviid C, Armitage AE, Kaul R, Beattie T, Lee JK, Li Y, Chotiyarnwong P, Dong T, Xu X, Luscher MA, MacDonald K, Ullum H, Klarlund-Pedersen B, Skinhoj P, Fugger L, Buus S, Mullins Jl, Jones EY, van der Merwe PA, McMichael AJ: Conflicting selective forces affect $T$ cell receptor contacts in an immunodominant human immunodeficiency virus epitope. Nat Immunol 2006, 7(2):179-189

10. Kijak GH, Currier JR, Tovanabutra S, Cox JH, Michael NL, Wegner SA, Birx DL, McCutchan FE: Lost in translation: implications of HIV-1 codon usage for immune escape and drug resistance. AIDS Rev 2004, 6(1):54-60.

11. Price DA, West SM, Betts MR, Ruff LE, Brenchley JM, Ambrozak DR, EdghillSmith Y, Kuroda MJ, Bogdan D, Kunstman K, Letvin NL, Franchini G, Wolinsky SM, Koup RA, Douek D: T cell receptor recognition motifs govern immune escape patterns in acute SIV infection. Immunity 2004.

12. Bihl F, Frahm N, Di Giammarino L, Sidney J, John M, Yusim K, Woodberry T, Sango K, Hewitt HS, Henry L, Linde CH, Chisholm JV, Zaman TM, Pae E, Mallal S, Walker BD, Sette A, Korber BT, Heckerman D, Brander C: Impact of HLA-B alleles, epitope binding affinity, functional avidity, and viral coinfection on the immunodominance of virus-specific CTL responses. J Immunol 2006, 176(7):4094-4101.

13. Yerly $\mathrm{D}$, Heckerman $\mathrm{D}$, Allen TM, Chisholm JV, Faircloth $\mathrm{K}$, Linde $\mathrm{CH}$, Frahm N, Timm J, Pichler WJ, Cerny A, Brander C: Increased cytotoxic Tlymphocyte epitope variant cross-recognition and functional avidity are associated with hepatitis C virus clearance. J Virol 2008, 82(6):3147-3153.

14. Zuñiga R, Lucchetti A, Galvan P, Sanchez S, Sanchez C, Hernandez A, Sanchez H, Frahm N, Linde C, Hewitt HS, Hildebrand WH, Altfeld M, Allen T, Walker B, Korber B, Leitner T, Sanchez J, Brander C: Relative dominance of Gag p24 specific CTL is associated with HIV control. J Virology 2006, 80:3122-3125.

15. Masemola A, Mashishi T, Khoury G, Mohube P, Mokgotho P, Vardas E, Colvin M, Zijenah L, Katzenstein D, Musonda R, Allen S, Kumwenda N, Taha T, Gray G, McIntyre J, Karim SA, Sheppard HW, Gray CM: Hierarchical targeting of subtype $C$ human immunodeficiency virus type 1 proteins by CD8+ T cells: correlation with viral load. J Virol 2004, 78(7):3233-3243.

16. Kiepiela P, Ngumbela K, Thobakgale C, Ramduth D, Honeyborne I, Moodley E, Reddy S, de Pierres C, Mncube Z, Mkhwanazi N, Bishop K, van der Stok M, Nair K, Khan N, Crawford H, Payne R, Leslie A, Prado J, Prendergast A, Frater J, McCarthy N, Brander C, Learn GH, Nickle D, Rousseau C, Coovadia H, Mullins Jl, Heckerman D, Walker BD, Goulder P: CD8+ T-cell responses to different HIV proteins have discordant associations with viral load. Nat Med 2007, 13(1):46-53.

17. Borghans JA, Molgaard A, de Boer RJ, Kesmir C: HLA alleles associated with slow progression to AIDS truly prefer to present HIV-1 p24. PLoS ONE 2007, 2(9):e920.

18. Sacha JB, Chung C, Rakasz EG, Spencer SP, Jonas AK, Bean AT, Lee W, Burwitz BJ, Stephany JJ, Loffredo JT, Allison DB, Adnan S, Hoji A, Wilson NA, Friedrich TC, Lifson JD, Yang OO, Watkins DI: Gag-specific CD8+ T lymphocytes recognize infected cells before AIDS-virus integration and viral protein expression. J Immunol 2007, 178(5):2746-2754.

19. Honeyborne I, Prendergast A, Pereyra F, Leslie A, Crawford H, Payne R, Reddy S, Bishop K, Moodley E, Nair K, van der Stok M, McCarthy N, Rousseau CM, Addo M, Mullins JI, Brander C, Kiepiela P, Walker BD, Goulder PJ: Control of human immunodeficiency virus type 1 is associated with HLA-B*13 and targeting of multiple gag-specific CD8+ T-cell epitopes. J Virol 2007, 81(7):3667-3672.

20. Leslie AJ, Pfafferott KJ, Chetty P, Draenert R, Addo MM, Feeney M, Tang $Y$, Holmes EC, Allen T, Prado JG, Altfeld M, Brander C, Dixon C, Ramduth D, Jeena P, Thomas SA, St John A, Roach TA, Kupfer B, Luzzi G, Edwards A, Taylor G, Lyall H, Tudor-Williams G, Novelli V, Martinez-Picado J, Kiepiela P, Walker BD, Goulder PJ: HIV evolution: CTL escape mutation and reversion after transmission. Nat Med 2004, 10(3):282-289.

21. Martinez-Picado J, Prado JG, Fry EE, Pfafferott K, Leslie A, Chetty S, Thobakgale C, Honeyborne I, Crawford H, Matthews P, Pillay T, Rousseau C, Mullins JI, Brander C, Walker BD, Stuart DI, Kiepiela P, Goulder P: Fitness cost of escape mutations in p24 Gag in association with control of human immunodeficiency virus type 1. J Virol 2006, 80(7):3617-3623.

22. Friedrich TC, Valentine $L E$, Yant $L$, Rakasz EG, Piaskowski SM, Furlott JR, Weisgrau KL, Burwitz B, May GE, Leon EJ, Soma T, Napoe G, Capuano SV, Wilson NA, Watkins DI: Subdominant CD8+ T-cell responses are involved in durable control of AIDS virus replication. J Virol 2007, 81(7):3465-3476. 
23. Bennett MS, Joseph A, Ng HL, Goldstein H, Yang OO: Fine-tuning of T-cell receptor avidity to increase HIV epitope variant recognition by cytotoxic T lymphocytes. Aids 2010.

24. Chen H, Piechocka-Trocha A, Miura T, Brockman MA, Julg BD, Baker BM, Rothchild AC, Block BL, Schneidewind A, Koibuchi T, Pereyra F, Allen TM, Walker BD: Differential neutralization of human immunodeficiency virus (HIV) replication in autologous CD4 T cells by HIV-specific cytotoxic T lymphocytes. J Virol 2009, 83(7):3138-3149.

25. Almeida JR, Price DA, Papagno L, Arkoub ZA, Sauce D, Bornstein E, Asher TE, Samri A, Schnuriger A, Theodorou I, Costagliola D, Rouzioux C, Agut H, Marcelin AG, Douek D, Autran B, Appay V: Superior control of HIV1 replication by CD8+ T cells is reflected by their avidity, polyfunctionality, and clonal turnover. J Exp Med 2007, 204(10):2473-2485.

26. Almeida JR, Sauce D, Price DA, Papagno L, Shin SY, Moris A, Larsen M, Pancino G, Douek DC, Autran B, Saez-Cirion A, Appay V: Antigen sensitivity is a major determinant of CD8+ T-cell polyfunctionality and HIVsuppressive activity. Blood 2009, 113(25):6351-6360.

27. Saez-Cirion A, Lacabaratz C, Lambotte $O$, Versmisse $P$, Urrutia A, Boufassa F, Barre-Sinoussi F, Delfraissy JF, Sinet M, Pancino G, Venet A: HIV controllers exhibit potent CD8 T cell capacity to suppress HIV infection ex vivo and peculiar cytotoxic T lymphocyte activation phenotype. Proc Natl Acad Sci USA 2007, 104(16):6776-6781.

28. Julg B, Williams KL, Reddy S, Bishop K, Qi Y, Carrington M, Goulder PJ, Ndung'U T, Walker BD: Enhanced anti-HIV functional activity associated with Gag-specific CD8 T-cell responses. J Virol 2010, 84(11):5540-5549.

29. Berger C, Frahm N, Price D, Mothe B, Ghebremichael M, Hartman K, Henry L, Brenchley J, Ruff L, Venturi V, Pereyra F, Sidney J, Sette A, Douek D, Walker B, Kaufmann D, Brander C: High functional avidity CTL responses to HLA-B-restricted Gag-derived epitopes associate with relative HIV control. J Virology 2011, 85(18):9334-9345.

30. Bunce M, O'Neill CM, Barnardo MC, Krausa P, Browning MJ, Morris PJ, Welsh Kl: Phototyping: comprehensive DNA typing for HLA-A, B, C, DRB1, DRB3, DRB4, DRB5 \& DQB1 by PCR with 144 primer mixes utilizing sequence- specific primers (PCR-SSP). Tissue Antigens 1995, 46(5):355-367.

31. Frahm N, Korber BT, Adams CM, Szinger JJ, Draenert R, Addo MM, Feeney ME, Yusim K, Sango K, Brown NV, SenGupta D, Piechocka-Trocha A, Simonis T, Marincola FM, Wurcel AG, Stone DR, Russell CJ, Adolf P, Cohen D, Roach T, StJohn A, Khatri A, Davis K, Mullins J, Goulder PJ, Walker BD, Brander C: Consistent cytotoxic-T-lymphocyte targeting of immunodominant regions in human immunodeficiency virus across multiple ethnicities. J Virol 2004, 78(5):2187-2200.

32. Frahm N, Nickle DC, Linde CH, Cohen DE, Zuniga R, Lucchetti A, Roach T, Walker BD, Allen TM, Korber BT, Mullins Jl, Brander C: Increased detection of HIV-specific $T$ cell responses by combination of central sequences with comparable immunogenicity. Aids 2008, 22(4):447-456.

33. Kiepiela P, Leslie AJ, Honeyborne I, Ramduth D, Thobakgale C, Chetty S, Rathnavalu P, Moore C, Pfafferott KJ, Hilton L, Zimbwa P, Moore S, Allen T, Brander C, Addo MM, Altfeld M, James I, Mallal S, Bunce M, Barber LD, Szinger J, Day C, Klenerman P, Mullins J, Korber B, Coovadia HM, Walker BD, Goulder PJ: Coevolutionary influences of HIV and HLA: the dominant role of HLA-B. Nature 2004, 432:769-774

34. Andre $P$, Groettrup $M$, Klenerman $P$, de Giuli $R$, Booth BL, Cerundolo V, Bonneville M, Jotereau F, Zinkernagel RM, Lotteau V: An inhibitor of HIV-1 protease modulates proteasome activity, antigen presentation, and $\mathrm{T}$ cell responses. Proc Natl Acad Sci 1998, 95(22):13120-13124.

35. Ali A, Jamieson BD, Yang OO: Half-genome human immunodeficiency virus type 1 constructs for rapid production of reporter viruses. J Virol Methods 2003, 110(2):137-142.

36. Hu Z, Kuritzkes DR: Effect of raltegravir resistance mutations in HIV-1 integrase on viral fitness. J Acquir Immune Defic Syndr 2010, 55(2):148-155.

37. Adnan S, Balamurugan A, Trocha A, Bennett MS, Ng HL, Ali A, Brander C, Yang OO: Nef interference with HIV-1-specific CTL antiviral activity is epitope specific. Blood 2006, 108(10):3414-3419.

38. Gibbs JS, Regier DA, Desrosiers RC: Construction and in vitro properties of HIV-1 mutants with deletions in "nonessential" genes. AIDS Res Hum Retroviruses 1994, 10(4):343-350.

39. Berger CT, Carlson JM, Brumme CJ, Hartman KL, Brumme ZL, Henry LM, Rosato PC, Piechocka-Trocha A, Brockman MA, Harrigan PR, Heckerman D, Kaufmann DE, Brander C: Viral adaptation to immune selection pressure by HLA class I-restricted CTL responses targeting epitopes in HIV frameshift sequences. J Exp Med 2010, 207(1):61-75.
40. Team RDC: R: A Language and Environment for Statistical Computing. $R$ Foundation for Statistical Computing; 2010 [http://www.R-project.org].

41. Liebminger A, Seyfang L, Filzmoser P, Varmuza K: A New Variable Selection Method Based on All Subsets Regression. 10th SSC 2007, Scandinavian Symposium on Chemometrics: 2007.

42. Seyfang L: Heuristiken zur Variablenselektion bei hochdimensionalen Daten. Institut für Statistik und Wahrscheinlichkeitstheorie, Technische Universität Wien, Vienna 2008.

43. Pérez-Álvarez S, Gomez G, Pérez-Álvarez N, Brander C: Technical Report: Use of comprehensive cohort data to identify host genetic and immunological and virological factors associated with relative in vivo control of HIV. Deparment of Statistics and Operational Research, Universitat Politècnica de Catalunya (UPC), Barcelona 2011.

44. Llano A, Frahm N, Brander C: How to Optimally Define Optimal Cytotoxic T Lymphocyte Epitopes in HIV Infection? In HIV Molecular immunology database. Edited by: Korber CB B, Walker B, Koup R, Moore J, Haynes B, Meyers G. Los Alamos, NM, USA: Los Alamos National Laboratory: Theoretical Biology and Biophysics; 2009:.

45. Goulder PJ, Brander C, Annamalai K, Mngqundaniso N, Govender U, Tang Y, He S, Hartman KE, O'Callaghan CA, Ogg GS, Altfeld MA, Rosenberg ES, Cao H, Kalams SA, Hammond M, Bunce M, Pelton SI, Burchett SA, McIntosh K, Coovadia HM, Walker BD: Differential narrow focusing of immunodominant human immunodeficiency virus gag-specific cytotoxic T-lymphocyte responses in infected african and caucasoid adults and children. J Virol 2000, 74(12):5679-5690.

46. Kawashima Y, Pfafferott K, Frater J, Matthews P, Payne R, Addo M, Gatanaga H, Fujiwara M, Hachiya A, Koizumi H, Kuse N, Oka S, Duda A, Prendergast A, Crawford H, Leslie A, Brumme Z, Brumme C, Allen T, Brander C, Kaslow R, Tang J, Hunter E, Allen S, Mulenga J, Branch S, Roach T, John M, Mallal S, Ogwu A, et al: Adaptation of HIV-1 to human leukocyte antigen class I. Nature 2009, 458(7238):641-645.

47. Leslie A, Matthews PC, Listgarten J, Carlson JM, Kadie C, Ndung'u T, Brander C, Coovadia H, Walker BD, Heckerman D, Goulder PJ: Additive contribution of HLA class I alleles in the immune control of HIV-1 infection. J Virol 2010, 84(19):9879-9888.

48. Yang OO, Kalams SA, Trocha A, Cao H, Luster A, Johnson RP, Walker BD: Suppression of human immunodeficiency virus type 1 replication by CD8+ cells: evidence for HLA class 1-restricted triggering of cytolytic and noncytolytic mechanisms. J Virol 1997, 71(4):3120-3128.

49. Rolland M, Heckerman D, Deng W, Rousseau CM, Coovadia H, Bishop K, Goulder PJ, Walker BD, Brander C, Mullins Jl: Broad and Gag-biased HIV-1 epitope repertoires are associated with lower viral loads. PLOS ONE 2008, 3(1):e1424.

50. Buchbinder SP, Mehrotra DV, Duerr A, Fitzgerald DW, Mogg R, Li D, Gilbert PB, Lama JR, Marmor M, Del Rio C, McElrath MJ, Casimiro DR, Gottesdiener KM, Chodakewitz JA, Corey L, Robertson MN: Efficacy assessment of a cell-mediated immunity HIV-1 vaccine (the Step Study): a double-blind, randomised, placebo-controlled, test-of-concept trial. Lancet 2008, 372(9653):1881-1893.

51. Rerks-Ngarm S, Pitisuttithum P, Nitayaphan S, Kaewkungwal J, Chiu J, Paris R, Premsri N, Namwat C, de Souza M, Adams E, Benenson M, Gurunathan S, Tartaglia J, McNeil JG, Francis DP, Stablein D, Birx DL, Chunsuttiwat S, Khamboonruang C, Thongcharoen P, Robb ML, Michael NL, Kunasol P, Kim JH: Vaccination with ALVAC and AIDSVAX to prevent HIV1 infection in Thailand. N Engl J Med 2009, 361(23):2209-2220.

52. Rolland M, Nickle DC, Mullins Jl: HIV-1 Group M Conserved Elements Vaccine. PLOS Pathogen 2007, 3(11):e157.

53. Addo M, Altfeld M, Rosenberg E, Eldridge B, Philips M, Habeeb K, Khatri A, Brander C, Robbins G, Mazzara G, Goulder P, Walker B: The HIV-1 regulatory proteins Tat and Rev are freqently targeted by cytotoxic $T$ lymphocyte (CTL) derived from HIV infected individuals. Proc Nat Acad Sci 2001, 98:1781-1786.

54. Kloverpris H, Karlsson I, Bonde J, Thorn M, Vinner L, Pedersen AE, Hentze JL, Andresen BS, Svane IM, Gerstoft J, Kronborg G, Fomsgaard A: Induction of novel CD8+ T-cell responses during chronic untreated HIV-1 infection by immunization with subdominant cytotoxic T-lymphocyte epitopes. Aids 2009, 23(11):1329-1340.

55. Altfeld M, Allen TM: Hitting HIV where it hurts: an alternative approach to HIV vaccine design. Trends Immunol 2006, 27(11):504-510.

56. Frahm N, Kaufmann DE, Yusim K, Muldoon M, Kesmir C, Linde $\mathrm{CH}$, Fischer W, Allen TM, Li B, McMahon BH, Faircloth KL, Hewitt HS, Mackey EW, 
Miura T, Khatri A, Wolinsky S, McMichael A, Funkhouser RK, Walker BD, Brander C, Korber BT: Increased sequence diversity coverage improves detection of HIV-specific T cell responses. J Immunol 2007, 179(10):6638-6650.

57. Ibarrondo J, Zuniga R, Farfan M, Suarez J, Mothe B, Llano A, Szinger J, Hildebrand W, Sanchez J, Korber B, Brander C: Crucial contribution of subdominant HLA-C allele restricted CTL responses to the control of HIV. AlDs Vaccine 2009: 2009; Paris .

58. Frahm N, Yusim K, Adams S, Sidney J, Hraber P, Hewitt HS, Linde CH, Woodberry T, Henry L, Listgarten J, Kadie C, Jojic N, Sango K, Brown NV, Pae E, Zaman T, John M, Mallal S, Marincola F, Walker BD, Sette A, Heckerman D, Korber BT, Brander C: Extensive HLA class I allele promiscuity among viral cytotoxic T lymphocyte (CTL) epitopes. Europ J Immunol 2007, 37:2419-2433.

59. Liu J, O'Brien KL, Lynch DM, Simmons NL, La Porte A, Riggs AM, Abbink P, Coffey RT, Grandpre LE, Seaman MS, Landucci G, Forthal DN, Montefiori DC, Carville A, Mansfield KG, Havenga MJ, Pau MG, Goudsmit J, Barouch DH: Immune control of an SIV challenge by a T-cell-based vaccine in rhesus monkeys. Nature 2009, 457(7225):87-91.

60. Reece JC, Loh L, Alcantara S, Fernandez CS, Stambas J, Sexton A, De Rose R, Petravic J, Davenport MP, Kent SJ: Timing of immune escape linked to success or failure of vaccination. PLoS One 2010, 5(9).

61. Letourneau S, Im EJ, Mashishi T, Brereton C, Bridgeman A, Yang H, Dorrell L, Dong T, Korber B, McMichael AJ, Hanke T: Design and pre-clinical evaluation of a universal HIV-1 vaccine. PLoS One 2007, 2(10):e984

62. Koga M, Kawana-Tachikawa A, Heckerman D, Odawara T, Nakamura H Koibuchi T, Fujii T, Miura T, Iwamoto A: Changes in impact of HLA class I allele expression on HIV-1 plasma virus loads at a population level over time. Microbiol Immunol 2010, 54(4):196-205.

63. Mullins J: A global AIDS vaccine based on conserved elements of the viral proteome AIDS Vaccine 2010: 2010; Atlanta, Georgia, USA.

64. Pereyra F, Addo MM, Kaufmann DE, Liu Y, Miura T, Rathod A, Baker B, Trocha A, Rosenberg R, Mackey E, Ueda P, Lu Z, Cohen D, Wrin T, Petropoulos CJ, Rosenberg ES, Walker BD: Genetic and immunologic heterogeneity among persons who control HIV infection in the absence of therapy. J Infect Dis 2008, 197(4):563-571.

doi:10.1186/1479-5876-9-208

Cite this article as: Mothe et al:: Definition of the viral targets of protective HIV-1-specific T cell responses. Journal of Translational Medicine 2011 9:208.

\section{Submit your next manuscript to BioMed Central and take full advantage of:}

- Convenient online submission

- Thorough peer review

- No space constraints or color figure charges

- Immediate publication on acceptance

- Inclusion in PubMed, CAS, Scopus and Google Scholar

- Research which is freely available for redistribution

Submit your manuscript at www.biomedcentral.com/submit 